\title{
STUDIES ON GERMLING DEVELOPMENT AND LIFE-HISTORY IN ULVACEAE AND MONOSTROMACEAE -PART II-
}

\author{
$\operatorname{AUTHOR}(S)$ :
}

Yoshida, Keisei

\section{CITATION:}

Yoshida, Keisei. STUDIES ON GERMLING DEVELOPMENT AND LIFE-HISTORY IN ULVACEAE AND MONOSTROMACEAE -PART II-. PUBLICATIONS OF THE SETO MARINE BIOLOGICAL LABORATORY 1970, 18(4): 243-273

\section{ISSUE DATE:}

\section{0-12-15}

URL:

http://hdl.handle.net/2433/175637

RIGHT: 


\title{
STUDIES ON GERMLING DEVELOPMENT AND LIFE-HISTORY IN ULVACEAE AND MONOSTROMACEAE PART II $^{122}$
}

\author{
KEISEI YOSHIDA \\ Suma Aquarium of Kobe City
}

With 22 Text-figures

CONTENTS

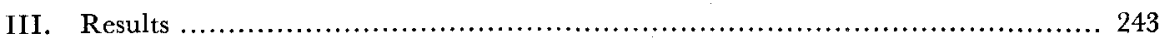

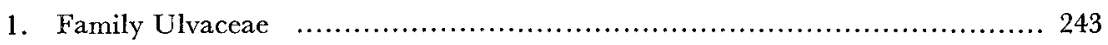

C. Genus Enteromorpha .................................................. 243

1. Enteromorpha flexuosa subsp. flexuosa .............................. 244

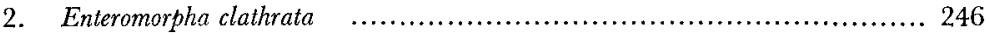

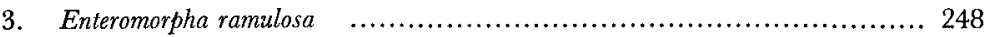

4. Enteromorpha prolifera ............................................... 268

5. Enteromorpha compressa ............................................... 269

6. Enteromorpha bulbosa $\gamma$ japonica.................................. 271

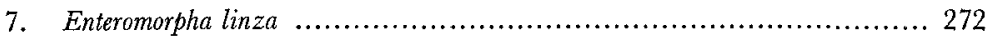

III. 1. Ulvaceae

C. Genus Enteromorpha LiNK, 1828

Thallus is usually tubular, simple or branched, consisting of one cell-layered membrane or rarely membranous consisting of two layers of cells except the basal part which is tubular. The cell-arrangement of the thallus in a surface view is either more or less regular or irregular. The number of pyrenoids within a cell is single in some species about two to several in others. These characters, however, are so changeable with ecological conditions that it is necessary for classification of Enteromorpha to consider the type of thallus development besides the morphological characters as pointed by Arasaki (1946).

The life-history in this genus is known to be a regular alternation of isomorphic generations, but some species such as $E$. linza sometimes repeat the asexual generation under certain conditions. Most of the species have three kinds of swarmers, namely

1) Contributions from the Seto Marine Biological Laboratory, No. 531.

2) Contributions from the Suma Aquarium of Kobe City, No. 74.

Publ. Seto Mar. Biol. Lab., XVIII (4), 243-273, $1970 . \quad$ (Article 19) 
2-flagellate male and female gametes and 4-flagellate zoospores. All of these reproductive cells and zygotes develop generally into tubular thalli, passing through almost the same processes. Namely these swarmers usually develop on germination into uniseriate filaments which grow afterwards into tubular bodies. In early stages of development, however, some species are simple while others are either sparsely or densely ramified. In some species such as $E$. bulbosa the germlings develop into creeping discs as a result of repeating longitudinal cell-divisions.

\section{Enteromorpha flexuosa (Wulfen, ex Roth) J. Agardh subsp. flexuosa}

Setchell \& Gardner, 1920, p. 225 and p. 256 (as E. flexuosa and E. tubulosa); Collins, 1928, p. 123; BLIDING, 1963, p. 73.

Fertile plants were collected in the intertidal zone from the rocky shores near the Seto Marine Biological Laboratory, Shirahama, in November 1965 and in February and March 1966. They were growing densely in tide-pools, $20-30 \mathrm{~cm}$ in diam. and about $15 \mathrm{~cm}$ in depth, but never on rocks exposed during the low tide (Fig. 12. H).

Thallus is soft, tubular, about $12 \mathrm{~cm}$ high, $1-2 \mathrm{~mm}$ broad, bearing a few small branches near the base, but sometimes simple (Fig. 12. A, B). In culture, however, some adult individuals are found branched in upper part (Fig. 12. B). The cells in a surface view are arranged in longitudinal and transverse rows almost throughout the thallus, quadrangular or rectangular in shape, $8-18 \times 18-22 \mu$ in the upper part of thallus, $18-20 \times 25-35 \mu$ in the lower, and issuing rhizoids near the thallus base (Fig. 12. G). In a sectional view, the cells are 17-18 $\mu$ high, 13-16 $\mu$ broad, and the thallus membrane is $22-24 \mu$ thick (Fig. 12. D, E). The chloroplast is parietal, containing one to three, mostly two, pyrenoids (Fig. 12. G).

Okamura (1936) enumerated E. flexuosa Wulf. f. angulosa KJELLm. in his list of Enteromorpha species as occurring at Hakodate on the authority of KJELLMAN (1897), but no others have ever reported this species from Japan. The cells of the material from Shirahama are $8-18 \times 18-22 \mu$ in size and are distinctly larger than the cells described for the plant from Hakodate $(6-8 \times 8-12 \mu)$. The material from Shirahama is identical with the description and illustration of the present species given by BLIDING (1963), especially in the appearance of branches and also in the presence of two to several pyrenoids in the chloroplast.

Reproduction and development: The gametophytes are dioecious, producing 2flagellate anisogametes which are elongated pear-shaped, provided with an eyespot, and sometimes acutely protruded at the posterior end (Fig. 10. A-C). Male gametes are $2.8 \times 6.8 \mu$ and female gametes are $3.6 \times 8.2 \mu$ on an average. They are positively phototactic. The sporophytes produce 4-flagellate zoospores which are elongated pear-shaped, $4.7 \times 8.7 \mu$ on an average, showing no clear phototaxis (Fig. 10. G).

Observations on the zygote development were carried out mainly with the 


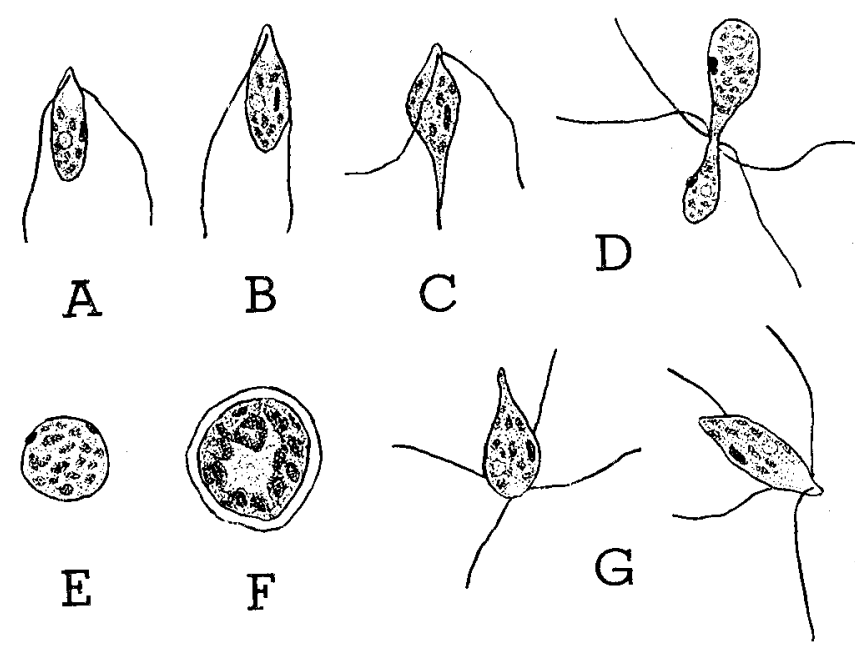

Fig. 10. Enteromorpha flexuosa subsp. flexuosa. A: male gamete. B: female gamete. C: gamete with posterior end acutely protruded. D: copulation of anisogamous gametes. E: zygote just settled on substratum. F : zygote with a thick wall, three days after copulation. G: zoospores. $A-G \times 1700$.

material collected on March 21, 1966. One day after conjugation, the zygote, $6 \mu$, diam., is surrounded by a membrane. Few days after, the cell becomes 8-9 $\mu$ diam., and the eyespots disappear. At this stage, one pyrenoid is observed in the cell (Fig. 10. F). After five days, some of the zygotes begin to germinate, dividing into two cells by a wall parallel or oblique to the substratum (Fig. 13. A, B). At this stage, the cells are usually furnished with two pyrenoids. By repeating transverse celldivisions, the germling becomes 3-7-celled after ten days, and 12-celled after 13 days, producing a simple monosiphonous filament (Fig. 13. C-F). Then the basal cells of the filaments repeat longitudinal cell-divisions and form a disc-like attachment (Fig. 13. H-L). The component cells of the attachment often produce several irregular projections which fasten firmly to the substratum (Fig. 13. E, F). When the erect part of a germling becomes 8-15-cell stage, longitudinal cell-divisions take place in the lower part of the filament and then also in the upper part to build a cylindrical body (Fig. 13. G, M). The erect filamients grow in three week to $220 \mu$ in height, and after about one month they become cylindrical and attain 0.8-1.1 mm in height (Fig. 13. M). The cells near the basal part of the erect filament issue rhizoids downwardly which grow covering the primary disc-like attachment.

At the end of June 1966 or three months after the start of the culture, the thalli attached on slides attained $5-7 \mathrm{~cm}$ in height and liberated zoospores (Fig. 14. J), and the zoospores germinated at once and developed into filamentous sporelings in the same way as the zygotes. When a slide bearing sporelings was placed on the bottom of a culture vessel and the light fell on the side of the slide, the filamentous sporelings 
grew towards the light and their basal cells issued long rhizoids while other lower cells also issued rhizoids one after another. In this case the sporelings never formed disclike attachments but they adhered to the substratum by rhizoids from the beginning of their development (Fig. 14. A-F). Thus the disc-like attachment in the present species is clearly distinguished from the disc in Blidingia minima in that the former is considered as a modification of the rhizoid.

Some of the zoospores liberated from the thalli which had been cultured in stagnant media developed into filamentous sporelings in a suspended state. These sporelings issued from the basal cells markedly elongated rhizoids (Fig. 14. G-I), and often also issued from the upper cells lateral branches which sometimes showed a reversed polarity (Fig. 14. H). These abnormalities observed in the suspended state of the sporelings are probably due to the changes of culture conditions, especially of the direction of light.

Four individuals among the fertile material collected on November 24, 1965, liberated 2-flagellate swarmers which did not conjugate with each other and were assumed to be female from their size. They germinated parthenogenetically and developed into new thalli which produced 4 flagellate zoospores. A similar cycle was reported by Möwus (1938) in $E$. intestinalis and E. compressa, and also by Kornmann (1956) in Percursaria percursa.

BuIding (1963) stated that the germlings of the present species were remarkably slender as a result of the fact that longitudinal cell-divisions began very lately, and his illustration (Fig. 40 e) shows that the germling is still uniseriate at the 23-cell stage. However, the longitudinal cell-divisions in my material took place commonly at 8 to 15-cell stages. Bliding (1955) also illustrated that the cells of germlings were furnished with two pyrenoids already at the 6-cell stage and that most of their cells at more advanced stages contained two pyrenoids. In these respects the material of the present study agrees well with BLIDING's plant.

\section{Enteromorpha clathrata (ROTH) GREvILLE}

Setchell \& Gardner, 1920, p. 260; Collins, 1928, p. 119; Bliding, 1933, p. 236; 1963, p. 106; Oramura, 1936, p. 19; Kylin, 1949, p. 28.

This alga was found growing in the vicinity of the Seto Marine Biological Laboratory on March 21, 1966, growing on rocky shores at a level below low water mark and scarcely exposed at low tide.

Thallus is tubular, more or less compressed in the upper part, about $4-5 \mathrm{~cm}$ high, densely ramified in all directions, about $0.5 \mathrm{~mm}$ broad in the main axis and about 2-3 $\mathrm{mm}$ broad in the upper part of branches (Fig. 15. A, B). The upper parts of a living thallus are yellowish-green in color as a result of the fact that the chloroplast occupies a small part of the cavity of each cell.

In a surface view, the cells are quadrangular or rectangular in shape, 10-17 $\times$ 
$10-12 \mu$ in the upper part of thallus, $10-17 \times 20-26 \mu$ in the lower, arranged in more or less regular rows, issuing rhizoids from near the base (Fig. 15. C, D). In a sectional view, the cells of the upper part of thallus are roundish rectangular, 15-18 $\mu$ high, the thallus membrane is $20-25 \mu$ thick (Fig. $15 . \mathrm{F}-\mathrm{H}$ ), and the chloroplast occupies a small part of the cell cavity (Fig. 15. C, D) containing 2-4 or more pyrenoids.

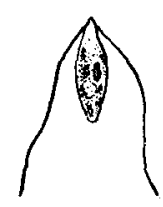

A

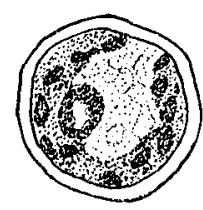

$\mathrm{E}$

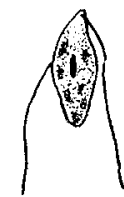

B

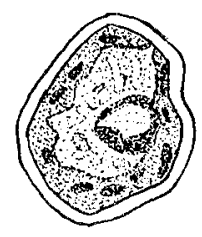

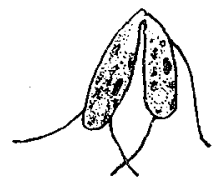

$\mathrm{C}$

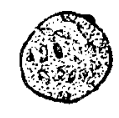

$\mathrm{D}$

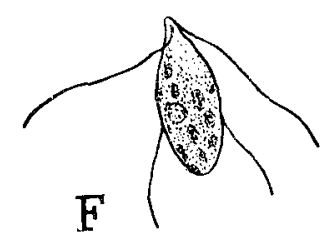

Fig. 11. Enteromorpha clathrata. A: male gamete. B: female gamete. C: copulation of anisogamous gametes. D: zygote settled on substratum. E: zygotes with a thick wall, 10 days after copulation. $\mathrm{F}$ : zoospore. A-F $\times$ 1700 .

Reproduction and development: The gametophytes are dioecious and anisogamous. The gametes are discharged through a round pore in the cell-wall (Fig. 15. E) into the hollow cavity of the tubular thallus, wherein the gametes swim actively for a while until they go outside through the splits formed in the thallus membrane. The male and female gametes, $2.3 \times 6.8 \mu$ and $2.9 \times 8.0 \mu$ in size respectively, are 2-flagellate, provided with an eyespot, and show positive phototaxis (Fig. 11. A, B). Conjugation of the gametes was observed on March 21, 1966. The fused couples of gametes became planozygotes which swam towards photo-negative side of the culture vessel, attached to the substratum and became round in shape (Fig. 11. C, D). After one day, they secreted a thin membrane. The zygotes increased their size gradually and their eyespots became smaller and smaller and finally disappeared. Ten days after conjugation, the round zygotes contained a single distinct pyrenoid (Fig. 11. E). The two-day-old zygotes were elongated, standing upright, and divided into two cells by a wall parallel or oblique to the substratum (Fig. 16. A). Then the germlings, by repeating transverse divisions, grew into erect simple filaments of uniseriate cells (Fig. 16. B-E). The basal cell of the germling which attached to the substratum produced several irregular projections and their cells divided cross- and lengthwise one after another to form a disc-like attachment (Fig. 16. E-H). Number of pyrenoids in a cell became two at the five-cell stage and three or more at later stages. When 
the erect filament was about 12-celled, longitudinal divisions took place in lower cells (Fig. 16. F). By repeating the longitudinal cell-divisions, the filament became consisting of compound rows of cells and it grew eventually to a tubular cylindrical thallus of the sporophyte. The sporophytes thus obtained in the culture are the only ones that produced zoospores on maturity during my observations of the present species. The zoospores, $5.7 \times 11.7 \mu$, were 4 flagellate and provided with an eyespot (Fig. 11. F). The eyespot was not so distinct as in the gametes. Sometimes it was quite obscure, though BLrDING (1933) illustrated the zoospores as having a distinct eyespot.

A remarkable characteristic of the present species observed during its thallus development is that the germlings are ramified in early stages of growth. They sometimes begin to be ramified in all directions as soon as their erect filaments reached $600 \mu$ in height (Fig. 17. B, G). Thirty-day-old germlings, 1-2 $\mathrm{mm}$ in height, were provided with 13 or more branches (Fig. 17. D-I). Two months after, the germlings on slides have grown into small thalli which were $3-4 \mathrm{~mm}$ high and $0.6 \mathrm{~mm}$ broad. Their cells contained a chloroplast which occupied a more or less limited space of the cell cavity as in the cells of the adult plants, and they had four or more pyrenoids (Fig. 17. J, K). In the beginning of June, the 75 -day-old thalli reached $2-3 \mathrm{~cm}$ in height and discharged from their apices many zoospores which germinated and developed in the same way as the zygotes.

BLIDING (1933) studied the development of this species and observed that the cells of germlings were provided with two pyrenoids as early as at the 2-cell stage and two to several pyrenoids at the 6-cell stage. Similar tendency was also observed in the present study.

\section{Enteromorpha ramulosa (J. E. SMITH) HOOKER}

\section{Japanese name: Hige-aonori (NAGURA)}

Yendo, 1911, p. 228; Nagura, 1921, p. 15; Collins, 1928, p. 120; Okamura, 1936, p. 19; Bliding, 1963, p. 119.

Adult plants of this species were collected at the vicinity of Tsunashirazu, Shirahama, on March 21, 1966. They were found interwoven around drifted twigs and ropes but not growing on rocks or algae in the littoral zone, though BLIDING (1963) described this alga as growing on stones and other algae at a depth of a few meters.

The thallus is dark-greenish color, tubulous, rather stiff, strongly and repeatedly

Fig. 12. Enteromorpha flexuosa subsp. flexuosa. A: a tuft of adult thalli. B: two adult plants, simple and branched, grown in culture. C: surface view of the middle part of thallus. D: cross-section of the upper margin of thallus. $E$ : cross-section of the middle part of thallus. F-G: cross-section of germling which is ca. $0.5 \mathrm{~cm}$ high $(\mathrm{F})$ and ca. $2 \mathrm{~cm}$ high $(\mathrm{G})$. $\mathrm{H}$ : rocky shore at Shirahama with numerous tide-pools in which this species was collected. $\mathrm{C}-\mathrm{F} \times 660, \mathrm{G} \times 170$. 
Life-History in Ulvaceae and Monostromaceae II
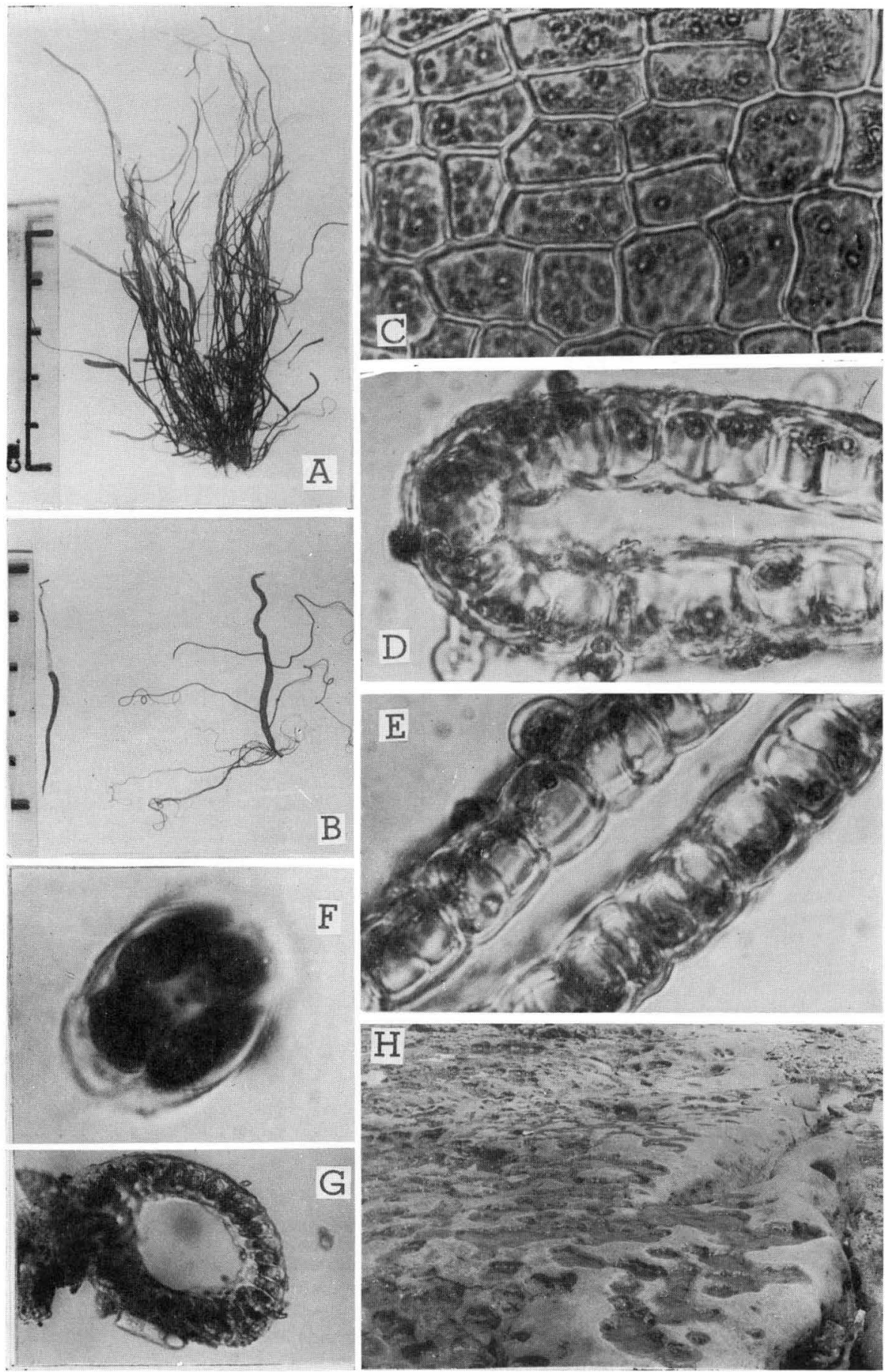

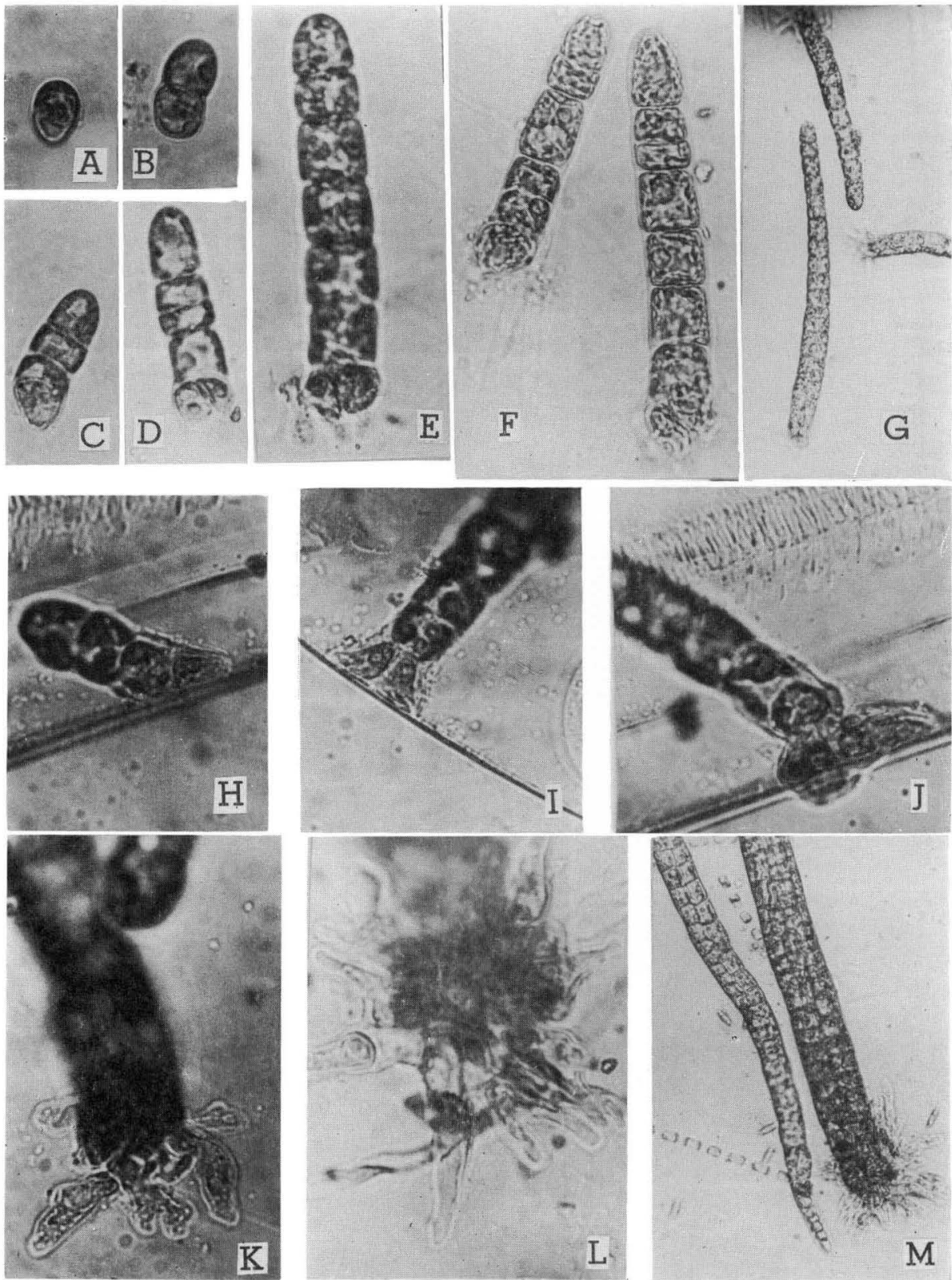

Fig.13. Enteromorpha flexuosa subsp. flexuosa. A-D: germlings at early stages of development. E-F : ca. 10-day-old germlings. E: germling with irregular projections on the basal cell. G: ca. 20-day-old germlings in which longitudinal cell-divisions are seen in the lower portion. H-J: germlings attached to a broken piece of slide showing development of attachment. K-L: basal part of germlings showing development. M: lower part of one-month old germling, showing well-developed attachment. A-F, H-L $\times 630, \mathrm{G}, \mathrm{M} \times 110$. 


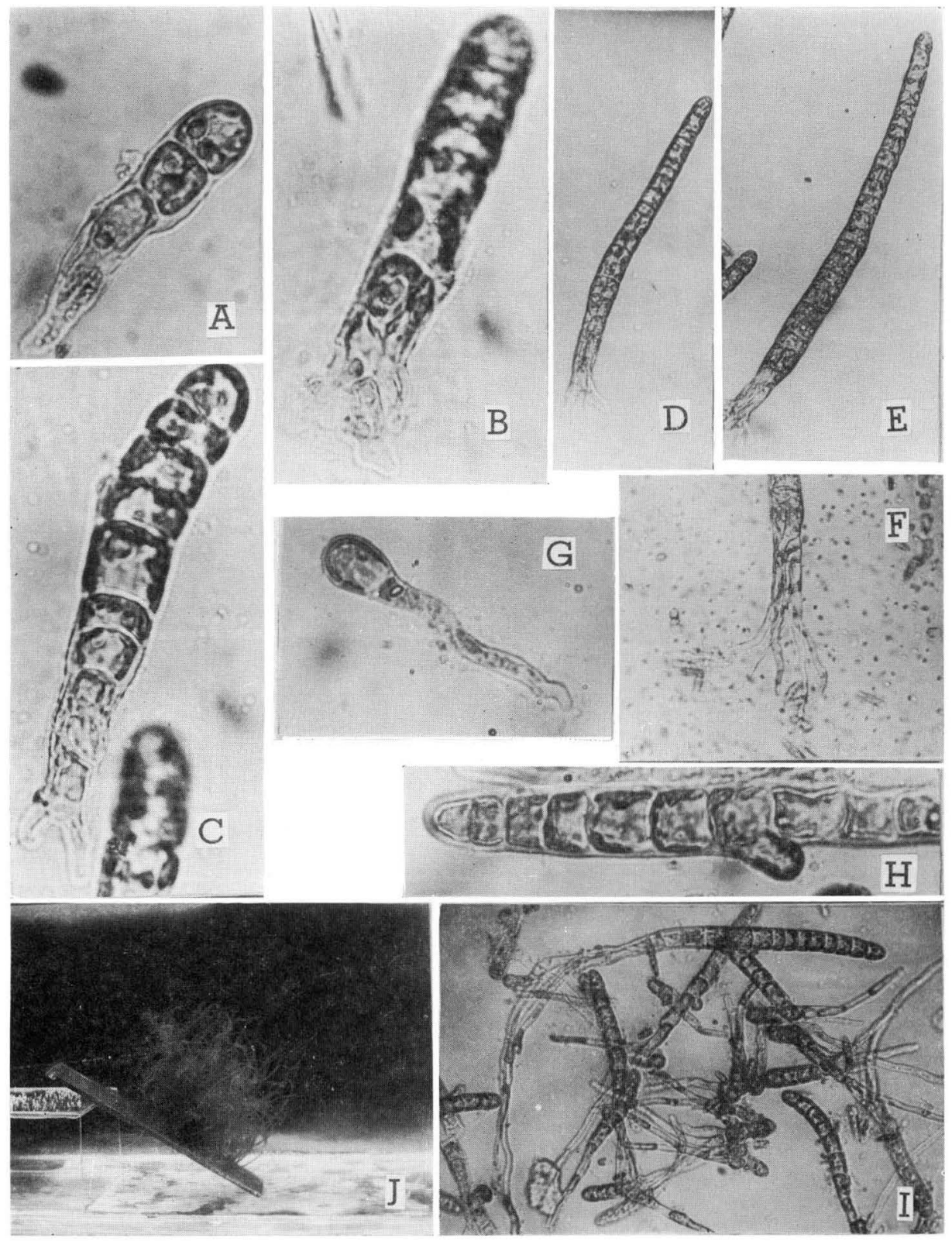

Fig. 14. Enteromorpha flexuosa subsp. flexuosa. A-F: germlings attached to slide on which the light fell horizontally. G-I: germlings cultured in suspension. G: two-celled germling with a long rhizoid. $\mathrm{H}$ : apical portion of a germling with a branch growing downwards. I : group of germlings in suspension. $\mathrm{J}$ : adult thalli growing on a slide. A-C, G-H $\times 660$, D-F, I $\times 170$ 

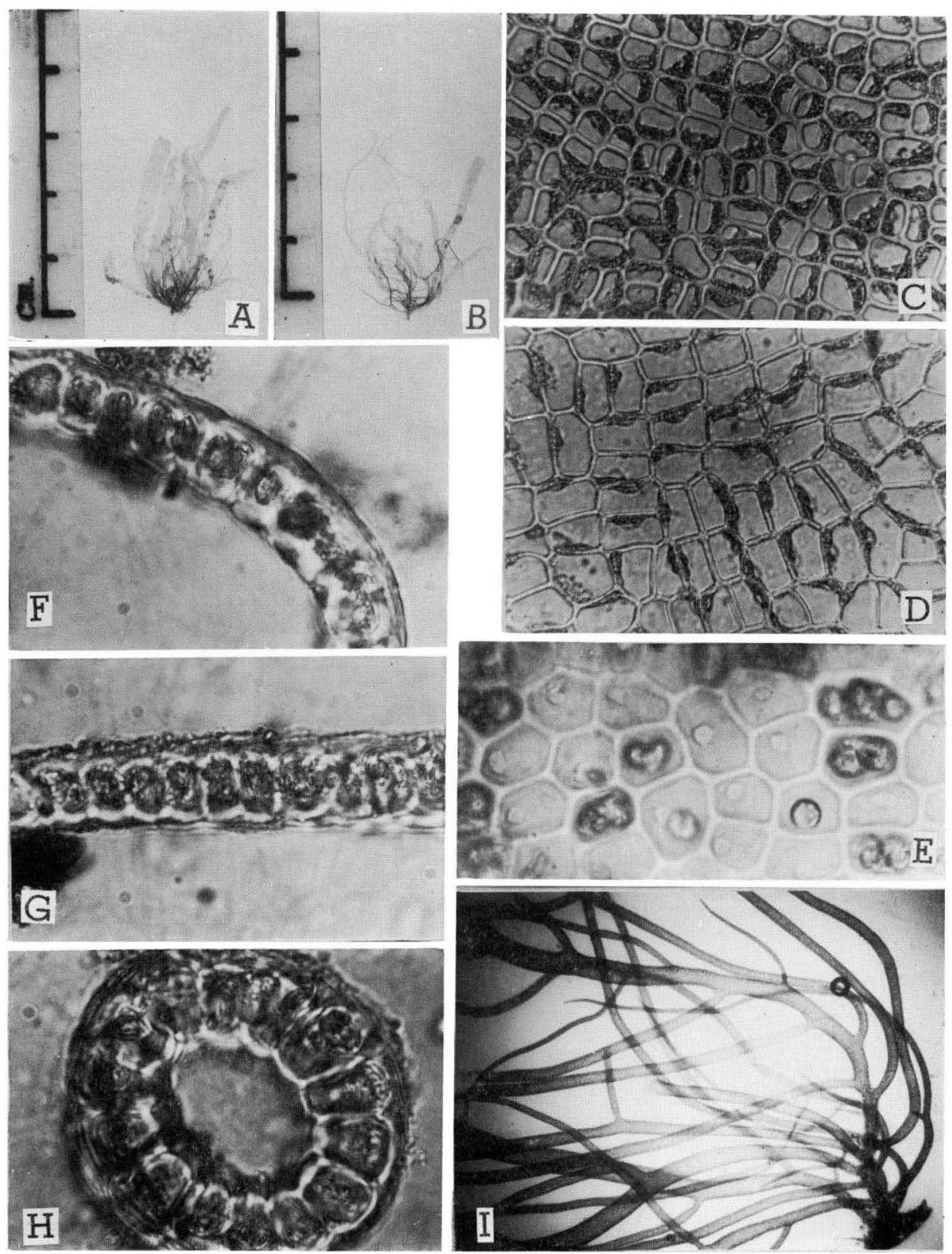

Fig. 15. Enteromorpha clathrata. A-B: adult plants. C-D: surface view of thallus, the middle (C) and lower (D) parts. E: surface view of fertile part of thallus showing zoospores and liberation pores. F-H: cross-section of the thallus, showing broad $(\mathrm{F}-\mathrm{G})$ and narrow $(\mathrm{H})$ parts. I: part of a small adult plant grown in culture. C-D $\times 400, \mathrm{E} \times 660, \mathrm{~F}-\mathrm{H} \times 600$, I $\times 24$. 

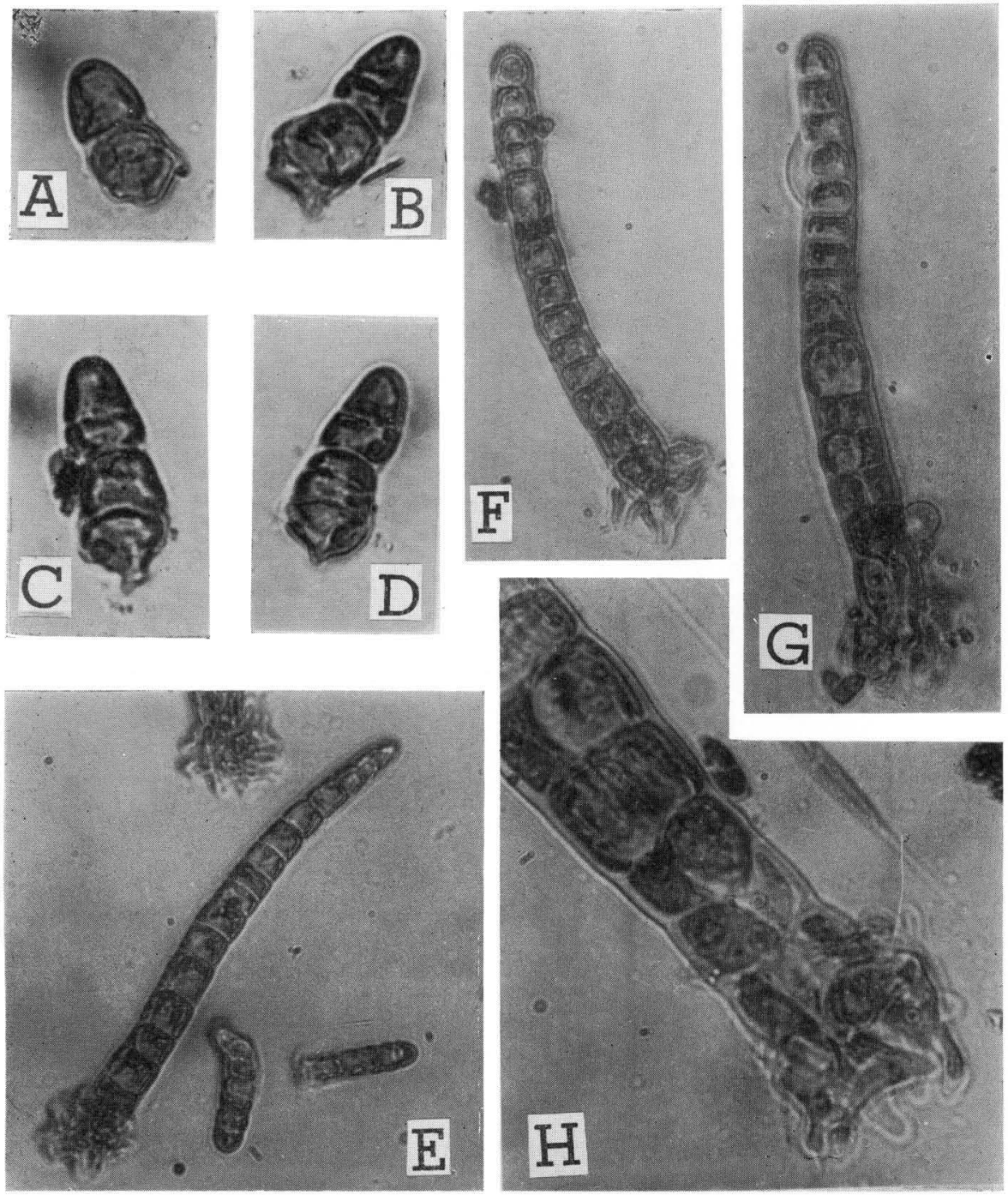

Fig. 16. Enteromorpha clathrata. A-D: young germlings. E-G: ca. 10-day-old germlings. H: basal portion of ca. 10 -day-old germling. A-D, $\mathrm{H} \times 800, \mathrm{E}-\mathrm{G} \times 300$. 

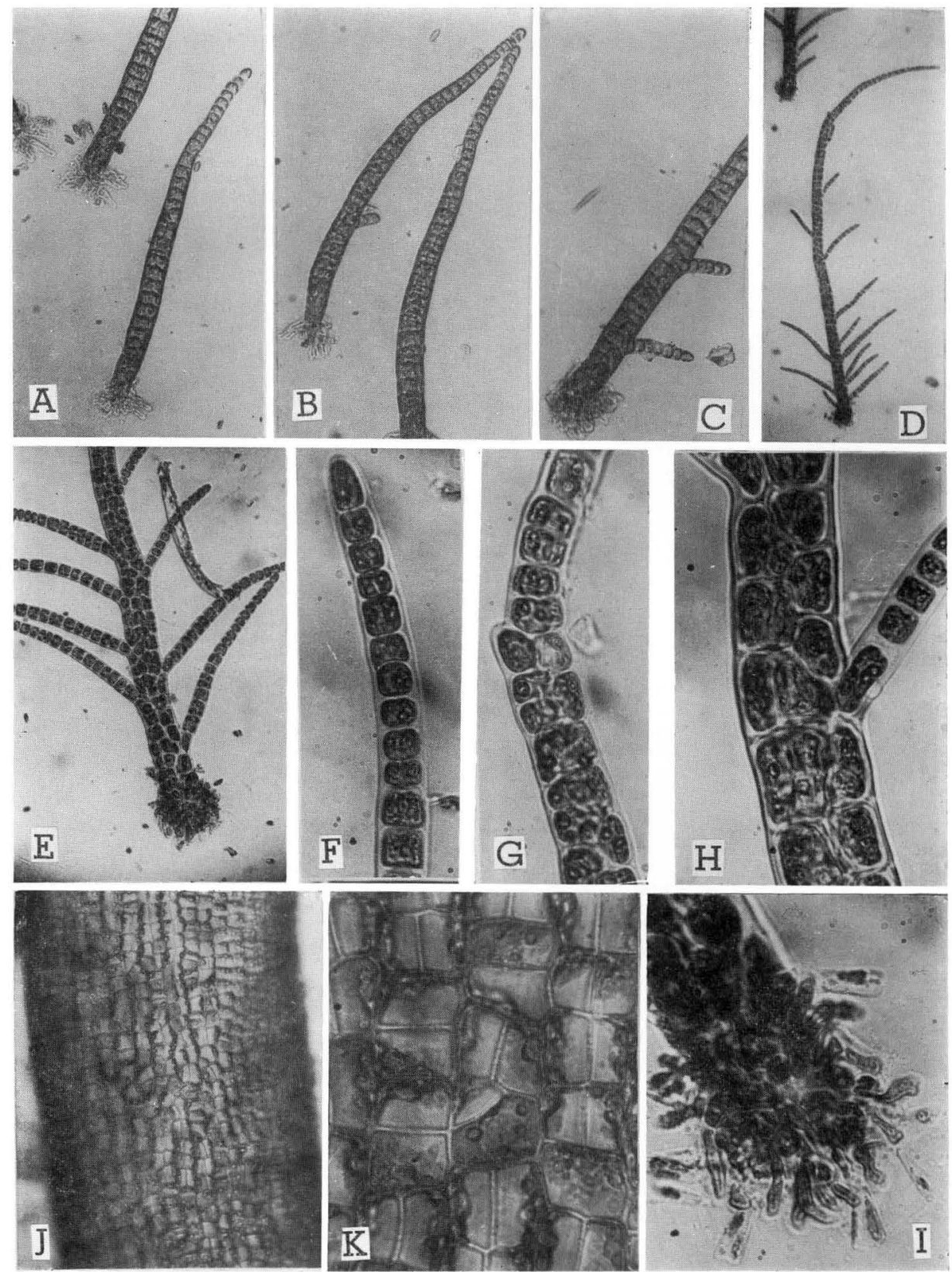

Fig. 17. Enteromorpha clathrata. A-C: ca. 20-day-old germlings, showing initial stage of ramification. D-I: one-month-old plants. F-H: upper and middle portions of a thallus, showing cells containing two to several pyrenoids. I: basal part showing attachment. J-K: surface view of small thalli cultured for two months, showing chloroplast occupying a small space of cell cavity. A-C, J $\times 90, \mathrm{D} \times 50, \mathrm{E} \times 70, \mathrm{~F}-\mathrm{I} \times 400, \mathrm{~K} \times 500$. 


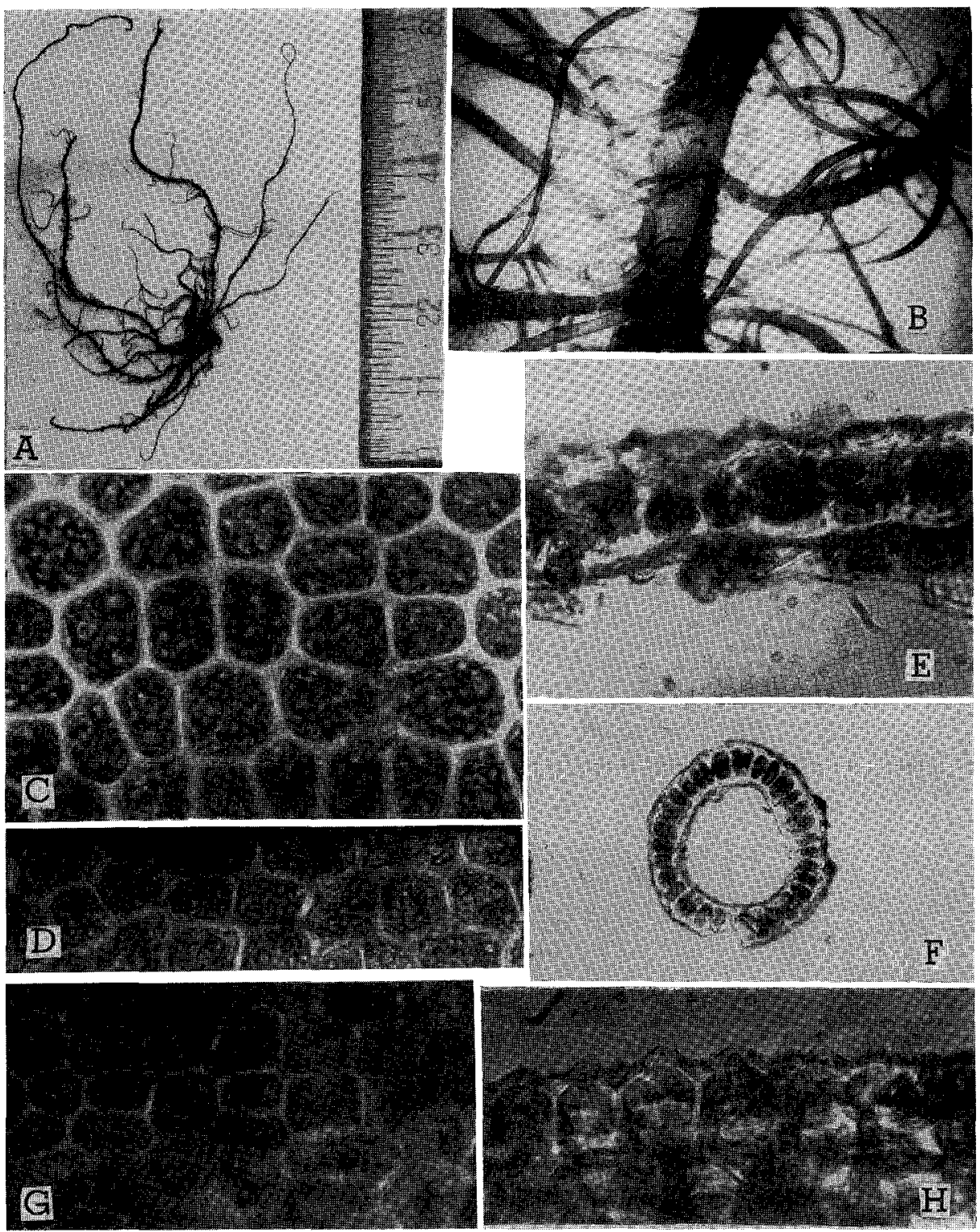

Fig. 18. Enteromorpha ramulosa. A: adult plant. B: ramification of thallus. C-D: surface view of thallus, showing main stem (C) and branch (D). E-F: cross-section of thallus, showing main stem (E) and branch $(\mathrm{F})$. G-H: fertile portion showing liberation pore of zoosporar.gium. G: surface view. $\mathrm{H}$ : cross-section. $\mathrm{B} \times 22, \mathrm{C}, \mathrm{E} \times 630, \mathrm{D}, \mathrm{G}, \mathrm{H} \times 470, \mathrm{~F} \times 110$. 

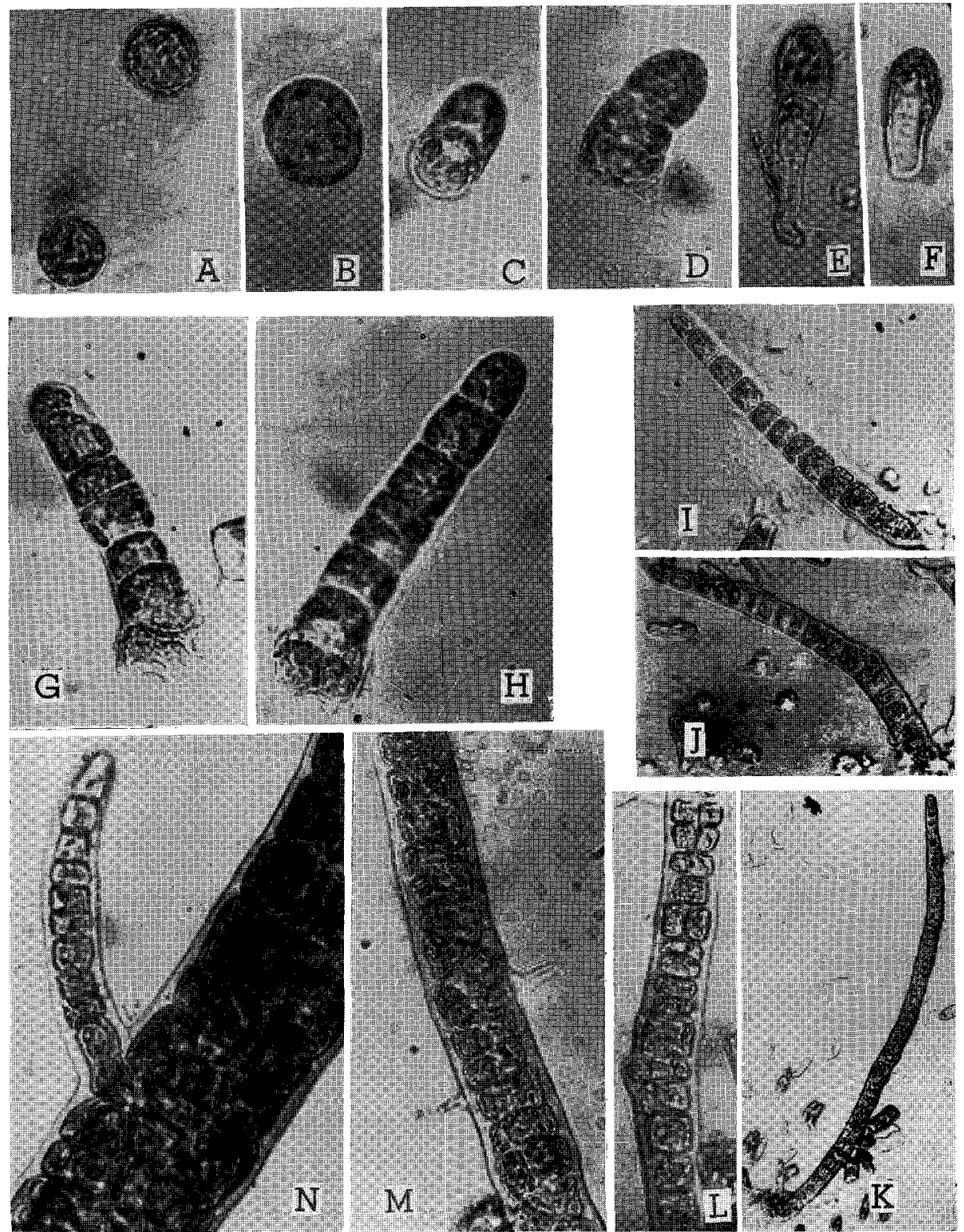

Fig. 19. Enteromorpha ramulosa. A-B: zoospores settled on substratum. C-F: initial stage of zoospore germination. G-H: ca. 10-day-old sporelings. I: 20-day-old sporeling. J : sporeling showing longitudinal divisions in some cells. K-M:40-day-old sporelings. L: initial stage of ramification. $\mathrm{M}$ : part of thallus showing irregular arrangement of cells. $\mathrm{N}$ : part of two-month-old plant. A-H $\times 630, \mathrm{I}, \mathrm{J}, \mathrm{L}, \mathrm{M} \times 380, \mathrm{~N} \times 470, \mathrm{~K} \times 90$. 

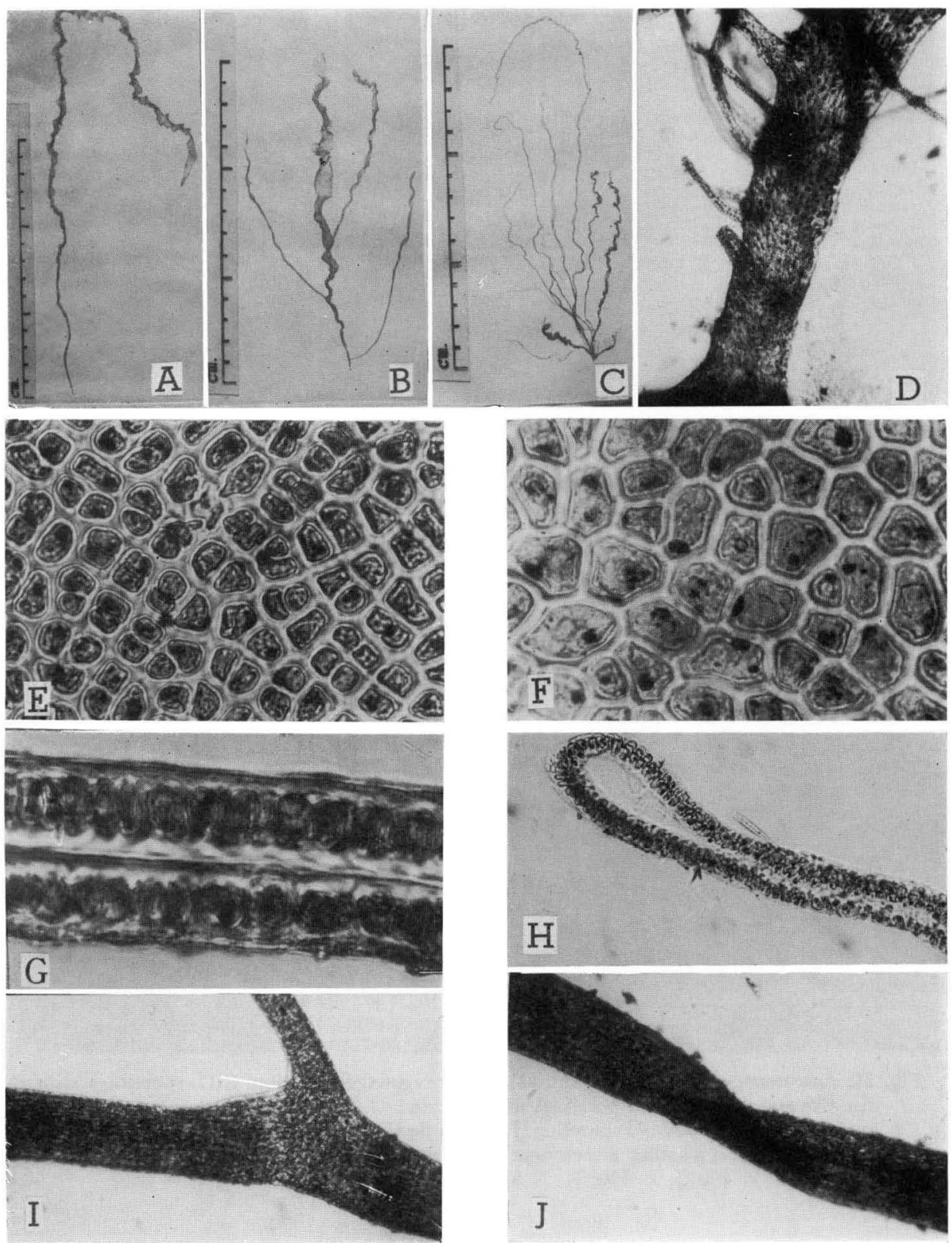

Fig. 20. Enteromorpha prolifera. A-C: adult plants. D: basal part of thallus showing thread-like branchlets. E-F: surface view of thallus, showing middle (E) and basal (F) parts. G: crosssection of flat thallus. $\mathrm{H}$ : cross-section through margin of flat thallus showing trabeculae in the marginal cavity. I-J: middle part of thalli grown in culture. D, I, J $\times 50$, E-G $\times 450$, $\mathrm{H} \times 140$. 


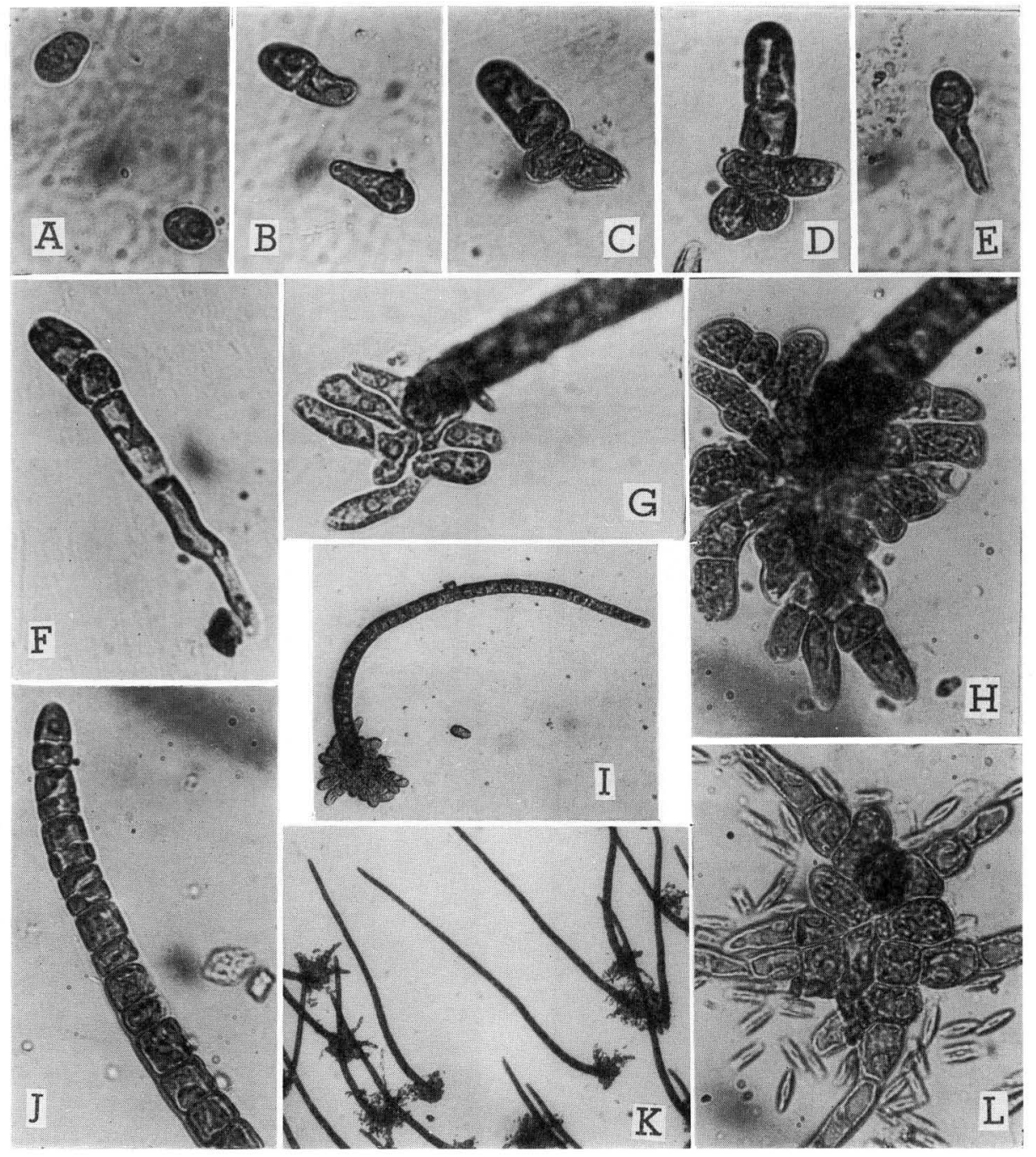

Fig. 21. Enteromorpha prolifera. A-B: initial stage of zygote germination. C-D: sporelings with a disc-like attachment. E-F : sporelings with a rhizoid. G-H: showing development of disc-like attachment. I: 40-day-old sporeling. J : apical portion of 40-day-old sporeling. K: 40-dayold sporelings. L: disc-like attachment forked before development of erect filament. A-H, $\mathrm{L} \times 600, \mathrm{I} \times 100, \mathrm{~J} \times 450, \mathrm{~K} \times 55$. 

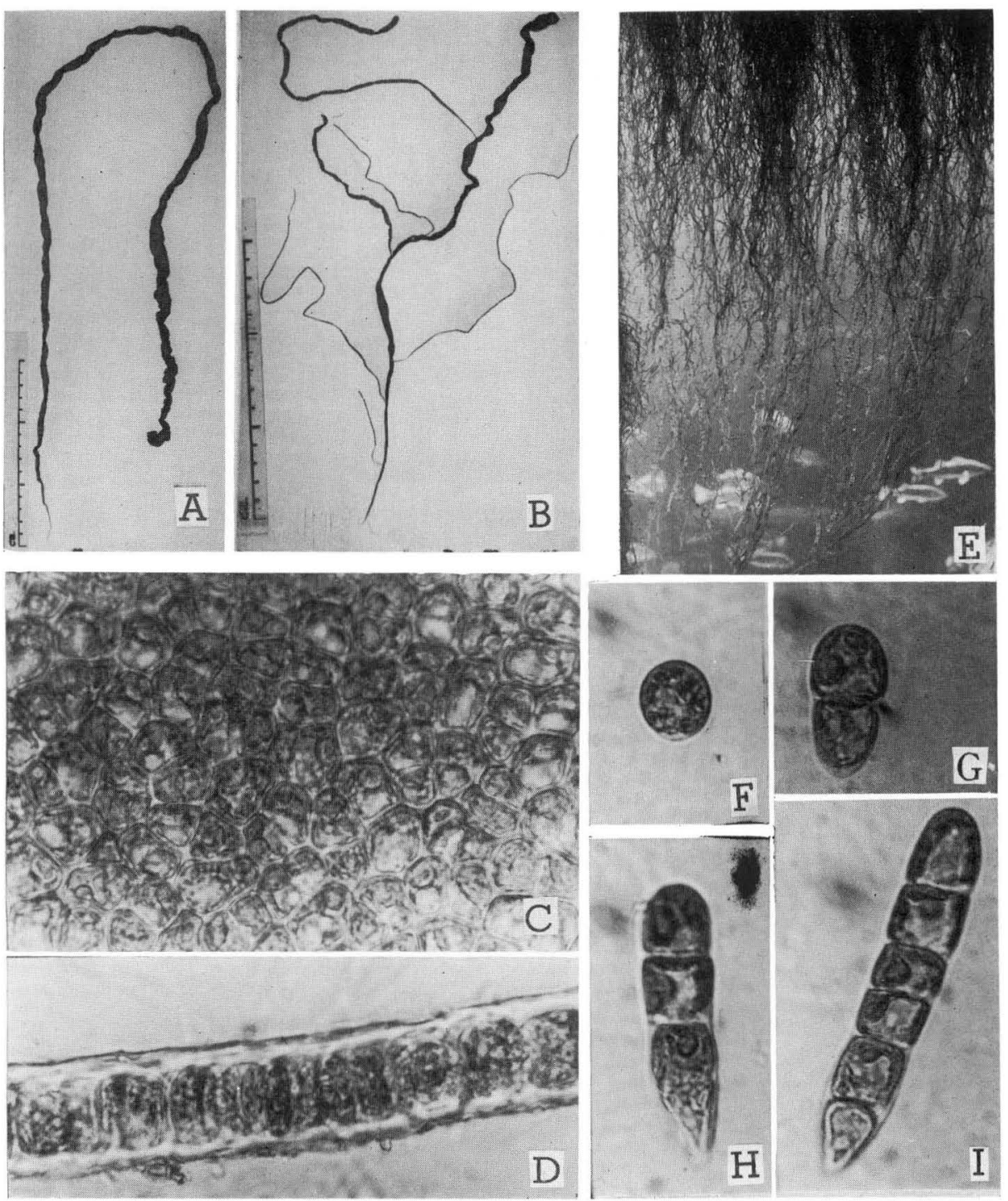

Fig. 22. Enteromorpha compressa. A-B: adult plants, simple and ramified in the upper portions. C: surface view of middle part of thallus. D: cross-section of middle part of thallus. E: thalli, up to ca. $120 \mathrm{~cm}$ long, growing on the upper portion of the inside wall of a big tank at Suma Aquarium, looked through a glass-window. F-I : initial stage of zygote germination. C-D, F-I $\times 660$. 

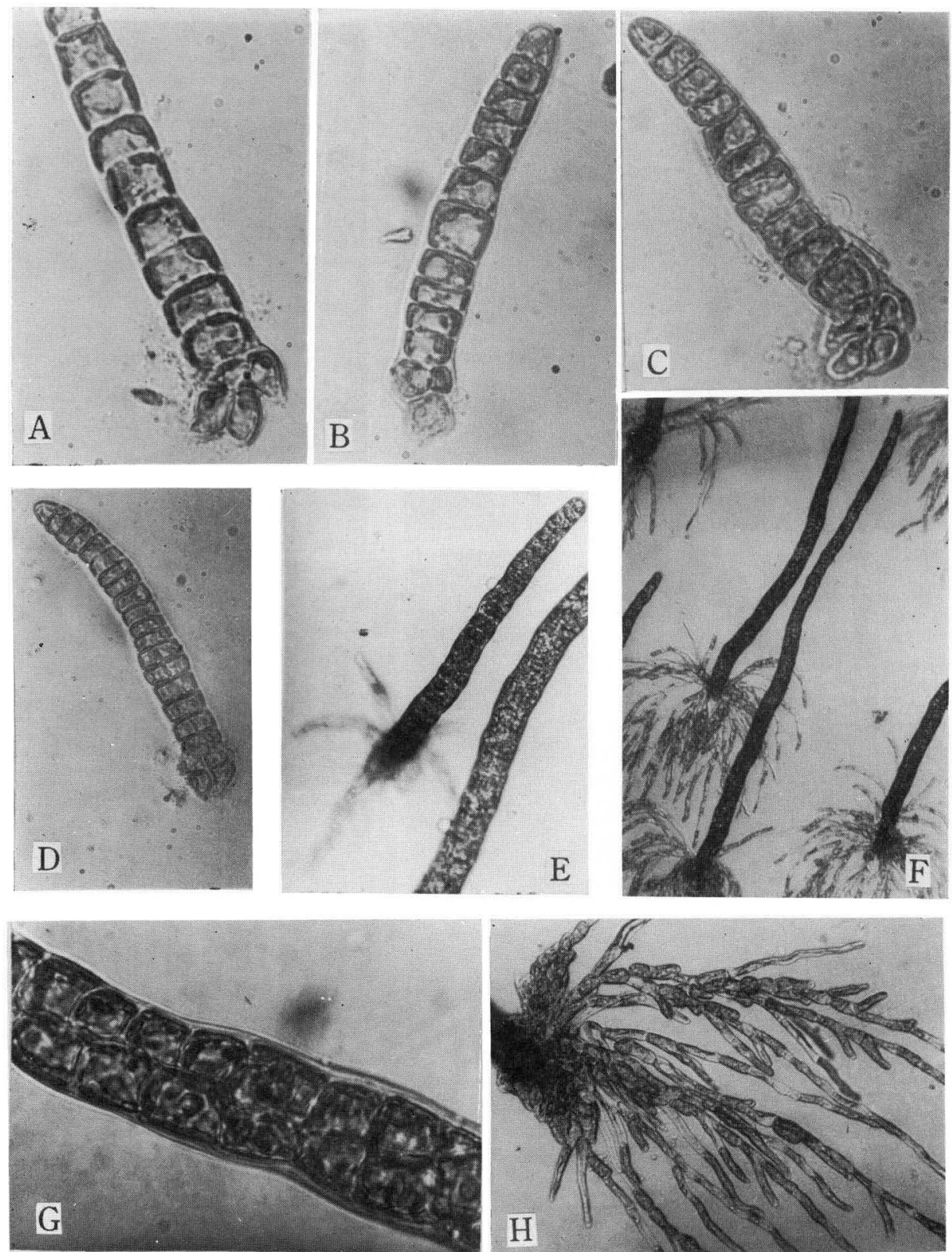

Fig. 23. Enteromorpha compressa. A-D: sporelings, 2-3 weeks old. C: sporeling in which longitudinal cell-divisions are seen in the lower portion. E: ca. one-month-old sporelings. F-H: two-month-old sporelings. G: surface view of middle part. $\mathrm{H}$ : a well-developed disc-like attachment, much ramified. $\mathrm{A}, \mathrm{G} \times 520, \mathrm{~B}, \mathrm{C} \times 470, \mathrm{D} \times 330, \mathrm{E}, \mathrm{H} \times 110, \mathrm{~F} \times 60$. 


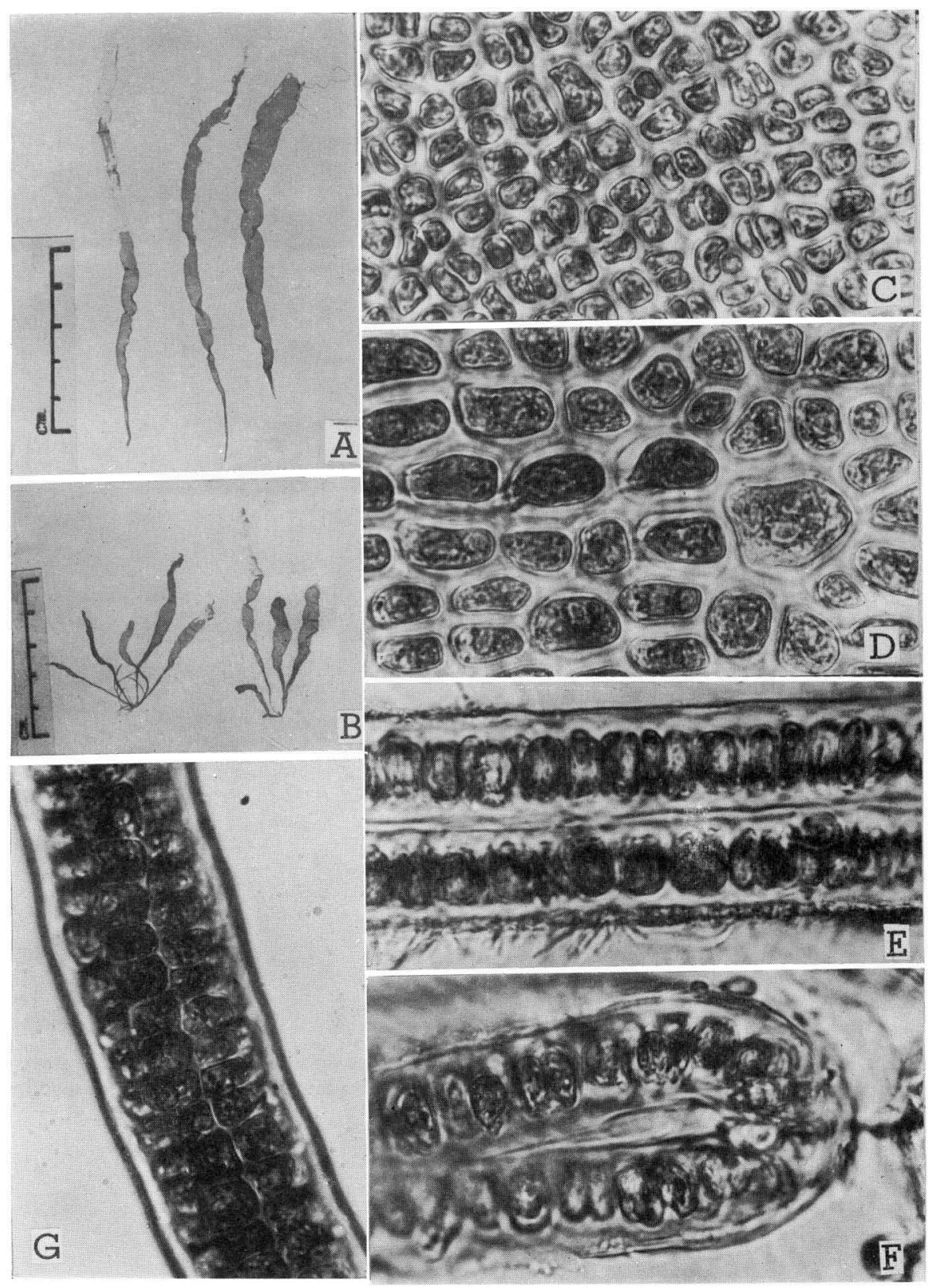

Fig. 24. Enteromorpha bulbosa $r$ japonica. A-B: adult plants, simple (A) and branched (B). C-D: surface view of thallus, showing middle $(\mathrm{C})$ and lower (D) parts. E-F: cross-section of thallus, showing middle part (E) and middle marginal portion (F). G: surface view of sporeling in culture. C-G $\times 660$. 

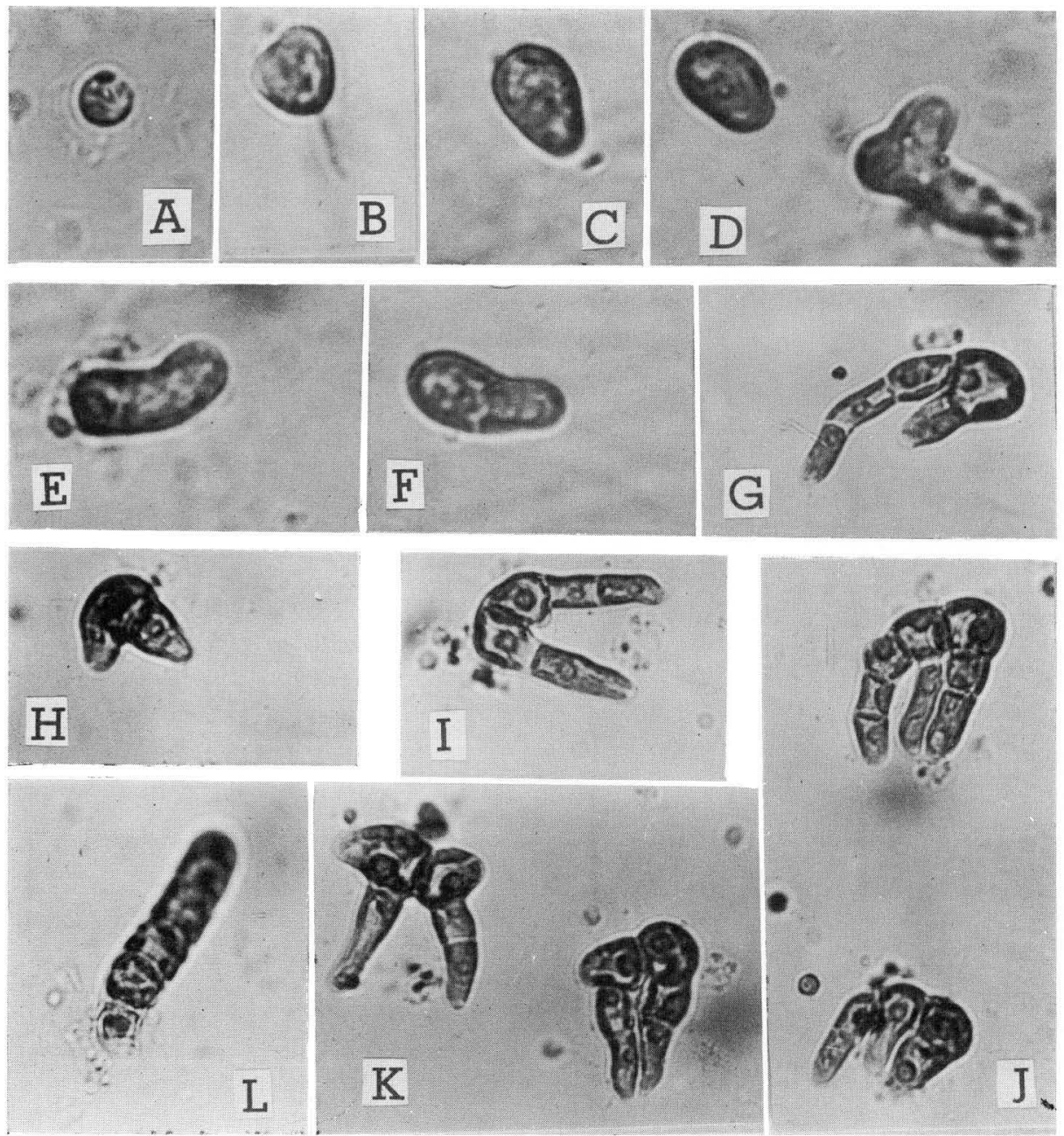

Fig. 25. Enteromorpha bulbosa $r$ japonica. A: zoospore settled on substratum. B-F: initial stage of zoospore germination. G-K: 10-day-old sporelings with a branched attachment. L: sporeling with no branched attachment. A-L $\times 1000$. 

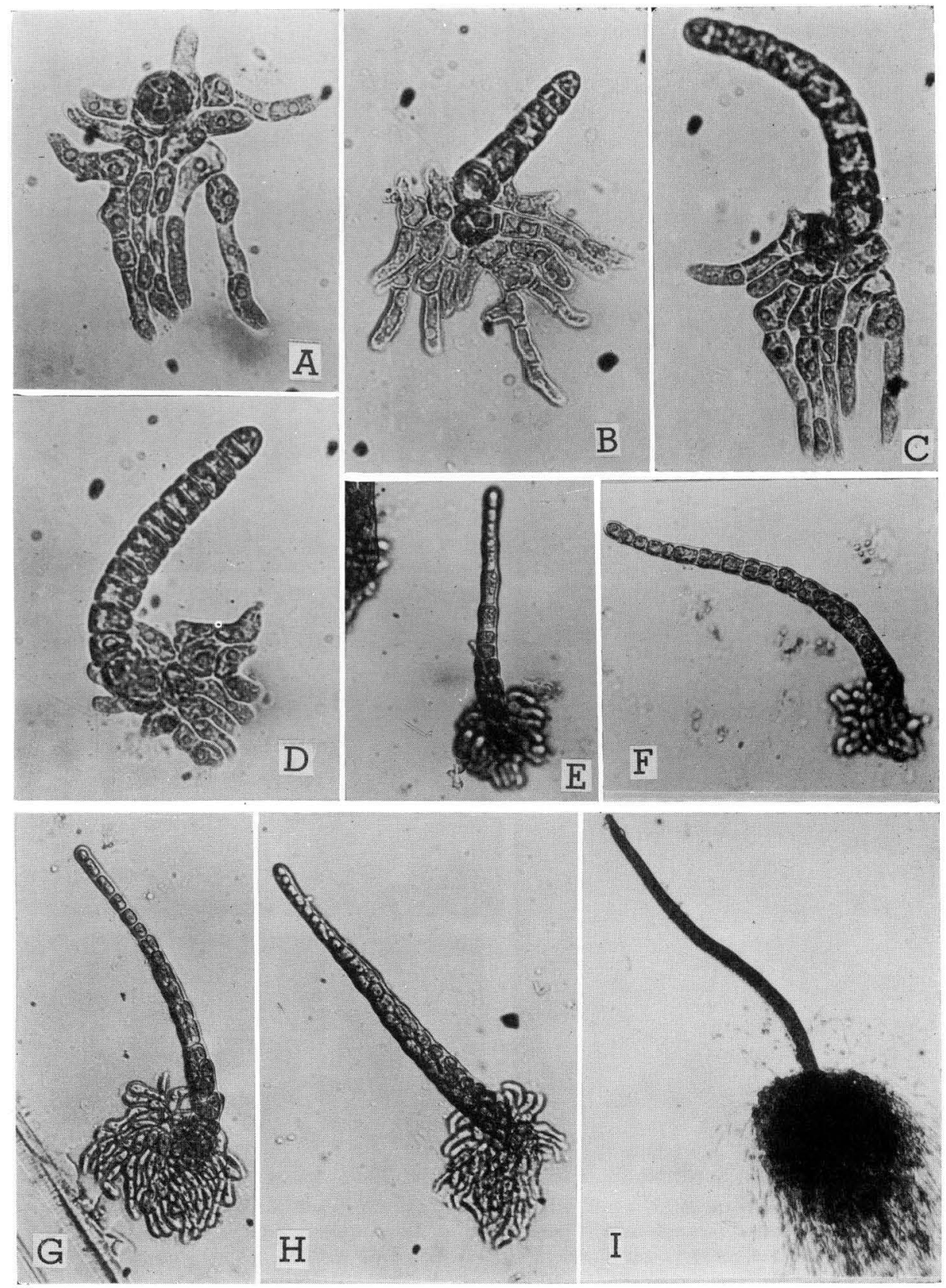

Fig. 26. Enteromorpha bulbosa $\gamma$ japonica. A: two-week-old sporeling, a cell of which has begun to elongate upwards. B-D: sporelings, 14-21 days old. E: ca. one-month-old sporeling in which longitudinal cell-divisions are seen in the lower erect portion. F-H: 40-50 day-old sporelings. I: 80 -day-old sporeling. A-D $\times 660, \mathrm{E}-\mathrm{H} \times 120, \mathrm{I} \times 60$. 

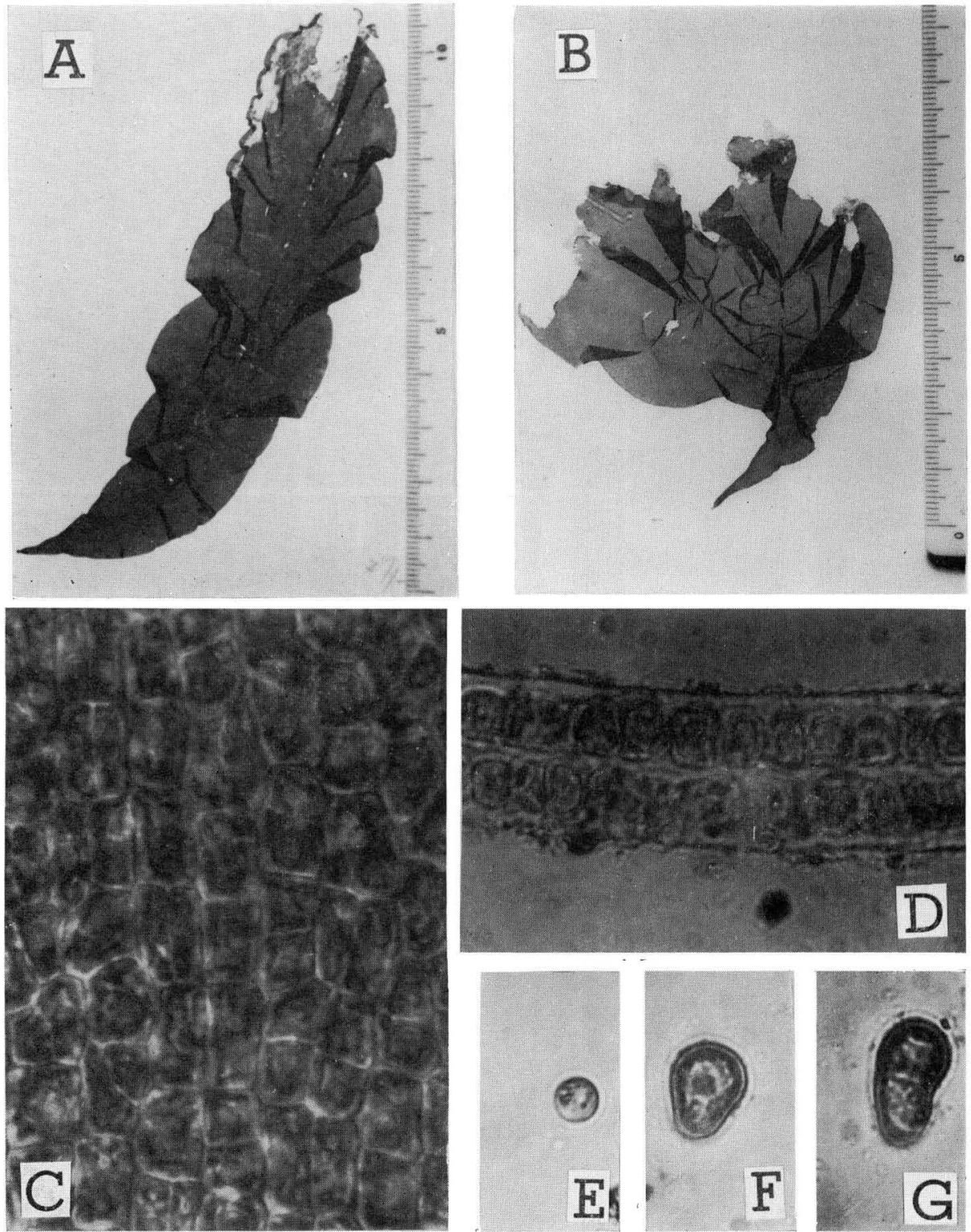

Fig. 27. Enteromorpha linza. A-B: adult plants. C: surface view of middle part of thallus. D: cross-section through middle part of thallus. E: zoospore settled on substratum. F-G: initial stage of zoospore germination. $\mathrm{C}, \mathrm{D} \times 400, \mathrm{E}-\mathrm{G} \times 1000$. 

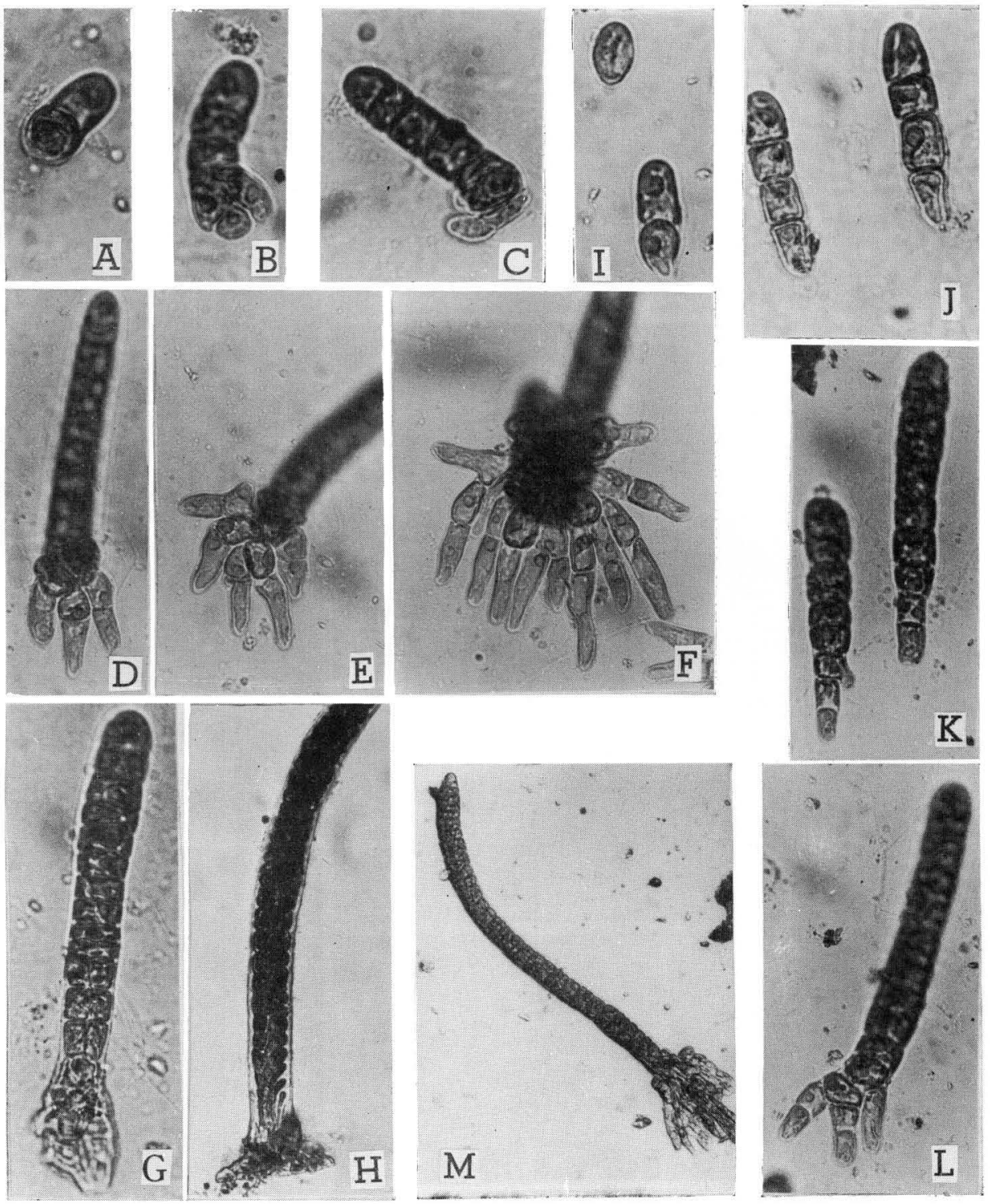

Fig. 28. Enteromorpha linza. A-F: sporelings with erect filament and disc-like attachment. D:14-day-old sporeling. F: basal part of ca. one-month-old sporeling, showing well -developed disc-like attachment. G: 20-day-old sporeling showing longitudinal divisions in several cells. H: ca. 50-day-old sporeling, showing secondary rhizoids covering the primary disc-like attachment. I-M: sporelings with creeping filament and attachment which is not disc-like. K: 14-day-old sporelings. M: 40-day-old sporeling. A-G, I-L $\times 550$, $\mathrm{H} \times 170, \mathrm{M} \times 110$. 

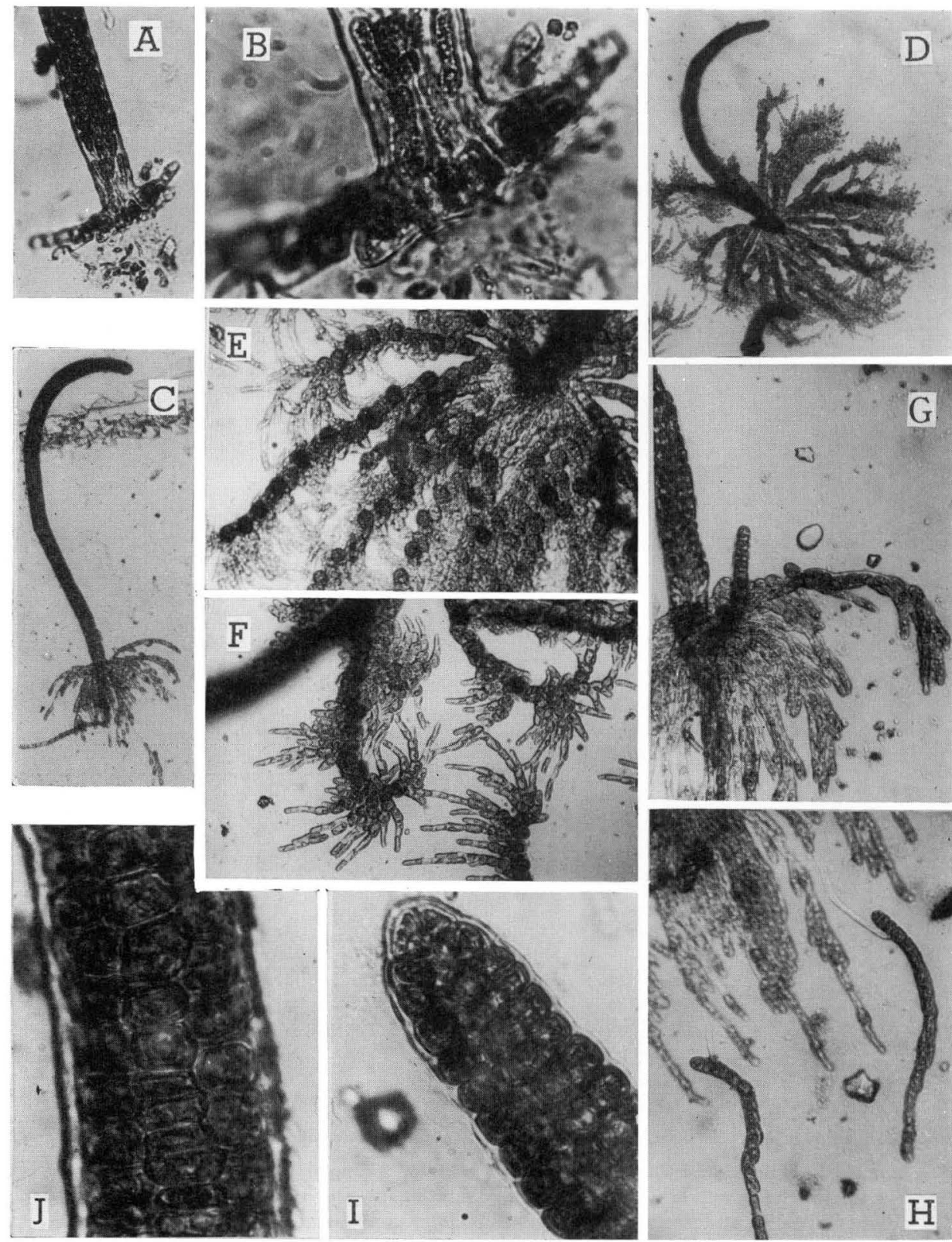

Fig. 29 Enteromorpha linza. A-B: sporelings showing secondary rhizoids covering the primary disc-like attachment. C-H: ca. two-month-old sporelings showing well-developed disc-like attachments on which numerous new erect filaments are growing. $\mathrm{H}$ : showing two young filaments which have become independent as a result of degeneration of the cells connecting them with the attachment of the mother plant. I-J : surface view of apical and middle portions of sporeling. A $\times 170, B, I-J \times 450$, C-D $\times 90, \mathrm{E}-\mathrm{H} \times 350$. 
ramified, and provided with many spines (Fig. 18. A, B). The main stem is about $1.5 \mathrm{~mm}$ in diameter. The cells are arranged irregularly in the stem, but in more or less longitudinal rows in the small branches. The cells in surface view are globular, roundish rectangular or polygonal. They are mostly rectangular and about $15-20 \times$ 25-30 $\mu$ in the main stem, while they are about $12-15 \times 20-30 \mu$ in the branch (Fig. 18. C, D). The cells of the main stem are globular or roundish square in sectional view, 17-20 $\mu$ high, and their membranes are about $30 \mu$ thick (Fig. 18. E, F). A single parietal chloroplast occupies nearly the whole space of the cell cavity and contains usually four, sometimes two to five, pyrenoids.

Reproduction and development: The specimens collected at Shirahama and brought to the laboratory in Kobe became fertile after about two months. The fertile cells discharged zoospores through a round pore in the cell-wall (Fig. 18. G, H). Liberation of gametes could not be observed though BLIDING (1963) reported that this species had an alternation of generations.

The zoospores are $6.0 \times 10.4 \mu$ in size, quadriflagellate, and provided with a single eyespot which is not always clearly seen (Fig. 30. A). They are not distinctly phototactic.

The zoospores were discharged from the fertile thalli on May 26, 1966. The discharged zoospores formed a "Gruppenbildung" for a while as observed by Hartmann (1929), and then they dispersed and swam away. The spores attached to the substrate became round in shape and attained to $9-13 \mu$ in diameter (Fig. 30. B, Fig. 19. A). At this stage they contained one to four pyrenoids. After one week they became about $18 \mu$ in diam. and some of them began to elongate in the direction vertical to the substrate (Fig. 19. G). Then they divided into two cells by a plane parallel or oblique to the substrate surface (Fig. 19. D). A few number of the germinating spores elongated from the first and grew into club-shaped germlings with attenuated base (Fig. 19. E, F). By repeating the transverse cell-divisions the erect part of germlings developed into a simple filament of uniseriate cells (Fig. 19. G-I). After twenty days the filament became 12-celled. On the other hand, the basal cell of germlings produced short projections and divided into two to several cells to form a disc-like attachment (Fig. 19. G, H).

The germling cells contain 2-5 pyrenoids. When the germlings are about 20-celled, longitudinal cell divisions take place in the lower or middle parts of the filaments (Fig. 19. J), then also in other parts and the filaments increase in thickness. After about 40 days, the germlings were about $570 \mu$ high, and some of them have already begun to branch (Fig. 19. K-M). After about two months, the germlings attained to $1.5 \mathrm{~mm}$ in height. Further development of germlings could not be observed with satisfaction as the media was contaminated with diatoms. However, I was able to confirm the following in E. ramulosa: (1) pyrenoids within a germling cell were two to several in number from the beginning of development, (2) germlings showed a tendency of ramification at an early stage of development as in E. clathrata, and (3) attachments of germling filaments developed in a similar way as that of $E$. 


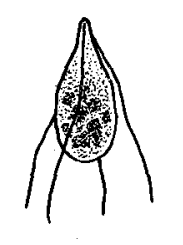

$\AA$

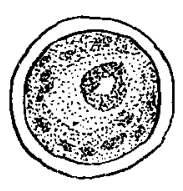

B
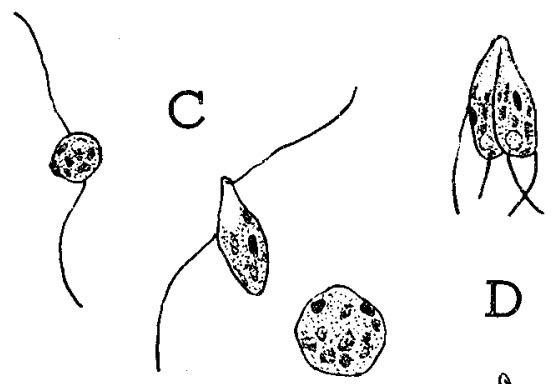

$\mathrm{D}$

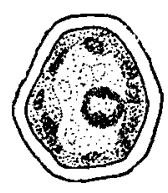

E

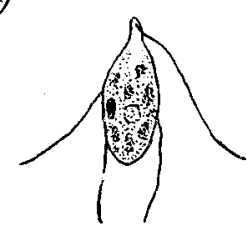

$\mathrm{F}$

$\mathrm{G}$

Fig. 30. A-B: Enteromorpha ramulosa. A: zoospore. B: sporeling with a thick wall, 10 days after settlement. C-G: Enteromorpha prolifera. C: gametes. D: copulation of isogamous gametes. E: zygote settled on substratum. F: zygote with a thick wall, one week after copulation, $\mathrm{G}$ : zoospore. A-G $\times 1600$.

clathrata and E. flexuosa.

\section{Enteromorpha prolifera (FL. DAN.) J. AGARDH \\ Japanese name: Suji-aonori (NAGURA)}

Setchell \& Gardner, 1920, p. 154; NAgura, 1921, p. 5; Collins, 1928, p. 122; Bliding, 1933, p.240; 1939, p. 134; 1963, p. 45; OKamUra, 1936, p. 14; Arasakr, 1946, p. 282; 1964, p. 7 (as E. clathrata); Kylin, 1949, p. 25; Tokida, 1954, p. 53; Segawa, 1956, p. 4; Segawa \& Kamura,1960, p. 6.

This alga was found growing on rocks in the lower intertidal zone at Fujishima in Shirahama on March 21, 1966. It covered densely the rocks, especially in the shade of pine trees on the beach.

Adult thalli are $10-40 \mathrm{~cm}$ high, about $1.5 \mathrm{~mm}$ broad in short individuals, about $10 \mathrm{~mm}$ broad in longer ones, profusely or sparsely branched, or sometimes apparently simple except near the basal part where thread-like small branches arise (Fig. 20. A-D). Main stem and branches are tubular below but compressed and membranous above. Margin of membranous part is flexuous, and it has, in sectional view, a hollow cavity between the two cell layers as in E. linza. The cavity is traversed by "trabeculae" which were first observed by Rosenvinge (1893) in E. prolifera and later by Tokida (1941) in E. linza (Fig. 20. H). Thallus cells, in surface view, are arranged in longitudinal rows in the upper part of thallus, but not in the lower, quadrangular or rectangular, sometimes pentagonal in shape, $7-11 \times 7-17 \mu$ in the upper part, whereas $12-15 \times 12-20 \mu$ in the lower (Fig. 20. E,F). The cells in the upper part in sectional view are roundish rectangular, 12-14 $\mu$ high, and their 
membrane is $17-20 \mu$ thick (Fig. 20. G, H). Chloroplast is parietal and contains a single big pyrenoid.

Materials for the present study agree well with the Typus I and Typus II of E. prolifera subsp. prolifera described and illustrated by BLiding (1963).

Reproduction and development: Gametophytes are dioecious. The gametes, $2.6 \times 8.3$ $\mu$ on an average, have two flagella and one eyespot, and are positively phototactic (Fig. 30. G). They have been reported by previous authors as anisogamous but I could not find any difference in size between male and female gametes. Bliding (1933, 1963) reported in this species from Sweden that male gametes were $6.0 \times 2.4 \mu$ and female $6.2 \times 3.5 \mu$, and ArAsaki (1946) measured the diameter of gametes of this species from Ise- and Mikawa-Bays, soon after they had adhered to the substratum, and reported that male gametes were $3.010 \pm 0.013 \mu$ and female $3.562 \pm 0.014 \mu$.

Zoospores are $4.3 \times 9.8 \mu$ in size on an average, and possess four flagella and one eyespot (Fig. 30. G).

Copulation test of the gametes was tried on March 22, 1966. Several days after the zygotes had fastened to substratum, the eyespot disappeared, and the zygotes containing a single big pyrenoid became ca. 7-10 $\mu$ in diam. (Fig. 30. F, Fig. 21. A). At this stage, some of the zygotes began to elongate. Seven days after the zygotes divided into two cells (Fig. 21. B), and the germlings thus formed grew into simple uniseriate filaments consisting of 3-7 cells (Fig. 21. C, D). Within two weeks, the basal cell of the filament attaching to substratum was elongated, branched, and formed a disk-like attachment by repeating cell-divisions (Fig. 21. C, D, G-I). Some of the filamentous germlings did not form a disc-like attachment but rhizoids (Fig. 21. E, F). Occasionally the germlings were at first in the form of a disc-like attachment and later gave rise to an erect filament (Fig. 21. L). The first longitudinal cell-division took place near the base of the erect part of the filaments when they became 25-32-celled. Then they were repeated successively resulting in the production of multiseriate filaments and eventually of cylindrical tubes. After 40 days, the germlings reached $1-1.5 \mathrm{~mm}$ in height (Fig. $21 . \mathrm{J}, \mathrm{K}$ ). When the culture was seven months old, there were obtained thread-like plants, $10-14 \mathrm{~cm}$ high, showing characteristics of the species. These results generally agree with those reported by BLIDING (1933) and ARASAKI (1946).

\section{Enteromorpha compressa (LinNAEUS) GREville}

\section{Japanese name: Hira-aonori (NAGURA)}

Setchell \& Gardner, 1920, p. 251; Nagura, 1921. p. 14; Collins, 1928, p. 121 ; Bliding, 1933, p. 224; 1963, p. 130; Okamura, 1936, p. 16; Möwus, 1938, p. 357; Arasaki, 1946, p. 281 ; 1964, p. 7; Kylin, 1949, p. 22; Segawa, 1956, p. 4.

This alga was found growing densely every year in a big show-tank of the Suma Aquarium, and I could make continuous observations of this alga with this tankcultured material. In 1965, the sea water poured into the tank on October 22nd con- 
tained numerous sawrmers, and one and a half months later, a dense growth of this species was found in the tank. Thereafter the growth of this alga in the tank was luxuriant from January to May, but it began to decline in June and finally disappeared in July.

Proliferation of the thallus was only observed in the plants growing on the northern wall of tank exposed to much more sunlight than the southern wall. From the intensity of the light that strikes upon the northern wall measured at noon of the April 22, 1966, it is concluded that light intensity surpassing 1,200 lux may be a factor that induces proliferation of the alga.

Adult thalli are $10-30 \mathrm{~cm}$, up to $120 \mathrm{~cm}$ high and $0.5-1.0 \mathrm{~cm}$ wide tubular, mostly compressed in the upper part, richly crisped, and sometimes wound spirally. Main stem is simple except near the base from where are issued many thread-like branches (Fig. 22. A, B, E). Main stem and branches are narrowed towards the base.

Thallus cells, in surface view, are roundish rectangular, ca. $12 \times 15 \mu$, and arranged irregularly (Fig. 22. C). The cells in sectional view are roundish rectangular, ca. $12 \mu$ high, and with a rather thin membrane, ca. $20 \mu$ thick (Fig. 22. D). Chloroplast is rather small, covering a part of the cell-walls, and with a single big pyrenoid (Fig. 22. C).

Reproduction and development: This alga has alternation of generations. The thalli producing 2-flagellate gametes are dioecious. Male gametes are $3.3 \times 7.2 \mu$, female $4.3 \times 7.5 \mu$ (Fig. 31. A, B). Zoospores are 4-flagellate, $5.2 \times 8.8 \mu$. (Fig. 31. C). These swarmers are all possessing one eyespot. Four days after settlement, the zygotes are ca. $8 \mu$ in diam., surrounded by cell membrane, and have no eyespot. One-week-old zygotes are 18-20 $\mu$ in diam. and they begin to elongate (Fig. 22. F),
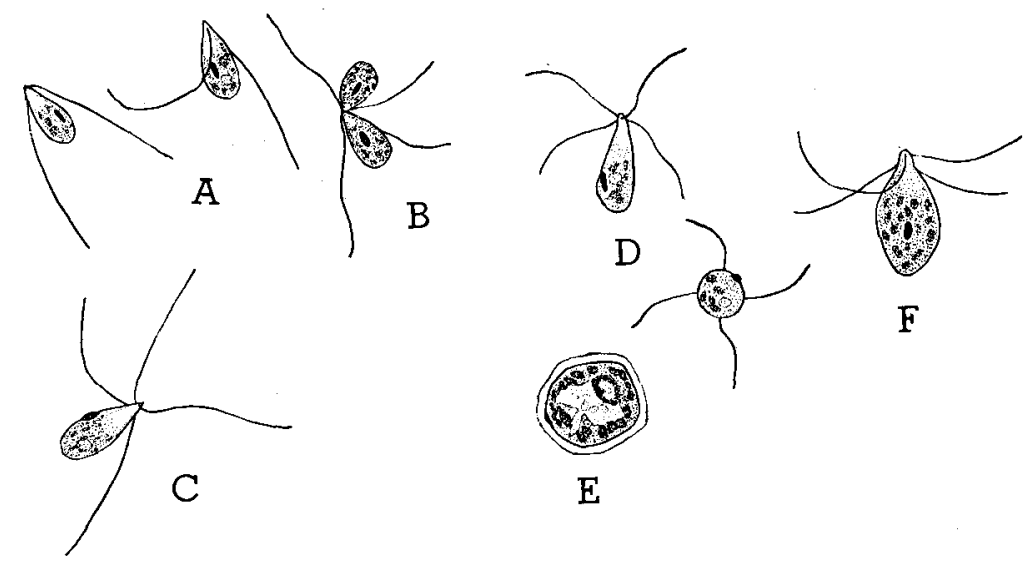

Fig. 31. A-G: Enteromorpha compressa. A: gametes. B: copulation of isogamous gametes. C: zoospore. D-E: Enteromorpha bulbosa $r$ japonica. D: zoospores. E: sporeling with a thick wall, 3 days after settlement. F: Enteromorpha linza. F: zoospore. A-F $\times 1000$. 
ca. 10-day-old ones are mostly two-celled (Fig. 22. G), and within two weeks, the germlings become 12-celled uniseriate filaments (Fig. 22. H, I; Fig. 23. A, B). Their basal cell attaches to substratum and forms a disc-like attachment by celldivisions (Fig. 23. A-D). The first longitudinal cell-division of the erect filament takes place near the base when it is 11-celled (Fig. 23. B, G). Chloroplast of germlingcells usually contains one big pyrenoid, but rarely two. Germlings grow further by repeating transverse and longitudinal cell-divisions and become tubulous. Germlings attain to $170-2,000 \mu$ in length when they are ca. two months old (Fig. 23. F-H). Cell arrangement of the erect filament is irregular from early stages of its growth (Fig. 23. E, G). Three-month-old germlings were $0.8-1.0 \mathrm{~cm}$ in length.

Development of zoospore- and parthenogamete-germlings resembles the abovementioned process of zygote development.

\section{Enteromorpha bulbosa (SUHR.) KUETz. $\gamma$ japonica KJELLMAN Japanese name: Fukuro-aonori (ARASAKI)}

Nagura, 1921, p. 11; Okamura, 1936, p. 17; Arasaki, 1946, p. 282; 1964, p. 7.

This alga was found growing on rocks in intertidal zone and also in places exposed to sewage at Seto of Shirahama in February and March, 1966.

Adult thalli are 10-15 cm high, two cell-layered and membranous in the upper part but tubular and attenuating into stipe in the lower. The membranous part is $0.5-0.8 \mathrm{~cm}$ broad, crisp, and with flexuous margins. Thalli are mostly simple but sometimes branched at the basal part (Fig. 24. A, B). Cells in the upper part are quadrangular or rectangular, 6-10 $\times 6-7 \mu$, in the lower more or less roundish, 10-15 $\times 13-19 \mu$, and in surface view they are generally arranged in longitudinal rows (Fig. 24. G, D). In cross-section through the upper part, the cells are roundish rectangular, ca. $15 \mu$ high, and with membrane 20-21 $\mu$ thick (Fig. 24. E). In the upper flattened membranous part, the two cell-layers are joined loosely with each other or separated partly from each other except along the margins which are always hollow and traversed by "trabeculae" (Fig. 24. F). Chloroplast is parietal and contains usually one pyrenoid but rarely two in the basal cells.

Simple type of this species resembles $E$. linza and the branched type resembles E. compressa in general appearance. NAGURA (1921) distinguished this species from $E$. linza by the following characters: (1) thallus is crumpled, (2) thallus is sometimes branched, (3) two cell-layers are joined partly, and (4) inner cell wall is much thicker than the outer. He also stated that the cells of this species were smaller in surface view, higher in cross section, and having thicker inner wall in cross section, than the cells of E. compressa. ARASAKI, who has identified his specimens with the present variety since 1964, reported in 1946 that he had discovered this species to have 2flagellate zoospores and a peculiar type of germling development. My specimens here described are generally identical with the descriptions of the present variety 
given by Nagura and Arasaki except the number of flagella in zoospores.

Reproduction and development: Swarmers liberated from ten individuals were examined on February 4 and March 12, 1966, to find that they were all 4-flagellate, asexual zoospores. The zoospores are elongated pear-shaped, ca. $9.4 \times 3.8 \mu$, with an eyespot, and negative in phototaxis (Fig. 31. D). Within two days, they become motionless and roundish, ca. $10 \mu$ in diam., and contain one pyrenoid (Fig. 25. A, Fig. 31. E). After three days they begin to germinate and most of the sporelings become two-celled after one week (Fig. 25. F). Further development of the sporelings is of a peculiar type among the Enteromorpha. Even at about three-cell stage, most of the sporelings begin to form a disc-like attachment by producing horizontal outgrowths in one direction, not in all directions as in Blidingia (Fig. 25. G-K). When the disclike attachment became 4 - or 10-celled, a certain cell among it began to elongate upwards and divided into two cells by a wall parallel to the substratum (Fig. 25. $\mathrm{H}$; Fig. 26. A). The upper one of these divided cells became an initial cell of the erect filament. After three weeks the erect uniseriate filaments became about 15 celled (Fig. 26. B-D). Longitudinal cell-divisions of the erect filaments first take place in their lower part when they are 15- to 18-celled and then gradually in the upper part (Fig. 26. E), resulting in the formation of tubulous thalli. On the other hand, the basal cells of the erect filaments issue rhizoids which form a firm holdfast covering the primary disc-like attachment. After about 80 days, the sporelings were $1.0-1.5 \mathrm{~mm}$ in length (Fig. 26. I) and in two months they grew to small cylindrical thalli, $10-15 \mathrm{~mm}$ high, $0.1 \mathrm{~mm}$ broad. The peculiar type of germling development observed in the present species was also reported in E. stipitata and E. gayralli by Dangeard (1959), and in $E$. hendayensis by Bliding (1963). These species differ from $E$. bulbosa $\gamma$ japonica in morphology of adult thalli.

\section{Enteromorpha linza (LinNaEUS) J. AGARDH}

\section{Japanese name: Usuba-aonori (OKAMURA)}

Setchell \& Gardner, 1920, p. 262 (as Ulva linza); Collins, 1928, p. 126; Briding, 1933, p. 234; 1939, p. 139; 1963, p. 127; Okamura, 1936, p. 15; 1952, p. 163; Yamada \& Sarto, 1938, p. 40; Tokida, 1941 , p. 49; 1954, p. 55; Arasaki, 1946, p. 284; 1964, p. 8; Arasaki \& Shihira, 1959, p. 92; Kylin, 1949; p. 19, Segawa, 1956, p. 5; Segawa \& Kamura, 1960, p. 3; Nirzeki, 1957, p. 1.

This alga grows abundantly all the year round on stones and concrete blocks in intertidal zone along the beaches at Suma, Akashi, and Iwaya near Kobe.

Adult thalli are up to $10-15 \mathrm{~cm}$ high, $1.5-6.0 \mathrm{~cm}$ broad, two cell-layered and membranous in the upper part but tubular and slender in the lower (Fig. 27. A, B), mostly simple but sometimes branched near the base. The membranous part is longitudinally folded, spirally wound, and undulate on the margin.

Cells in surface view of the membranous part are rectangular, $10-12 \times 14-16 \mu$, and arranged in longitudinal rows (Fig. 27. G), in sectional view they are roundish 
to rectangular, 18 $24 \mu$ high (Fig. 27. D). Cells have a parietal chloroplast and a single pyrenoid. Marginal portion of the membranous thallus is hollow and traversed by "trabeculae". Thickness of the single cell-layered thallus membrane is $27-30$ $\mu$ in the upper part and $30-45 \mu$ in the lower tubular part.

Reporduction and development: A continuous investigation on the swarmers and their development in the present species has been carried out in Kobe for five years 1962 to 1966 . The swarmers discharged from about 200 fertile individuals examined during the period from January to Decmber were all found to be 4-flagellate asexual spores. Neither 2-flagellate asexual swarmers (cf. Bliding, 1933; YAMAda \& SAIto, 1938) nor 2-flagellate gametes (cf. Möwus, 1938; ARASAKI, 1946) were observed in the present material.

The swarmers are elongate pear-shaped, about $6.0 \times 13.0 \mu$, and 4-flagellated. They have one eyespot and are negatively phototactic (Fig. 31. F). Settled and rounded swarmers are ca. $7 \mu$ in diam. (Fig. 27. E). After 3 days, a single pyrenoid was observed in the cells which had lost eyespot and begun to elongate (Fig. 27. F). Within one week, the cells became ca. $14 \mu$ in diam. After 10 days, the germlings were 2-celled, and after 12 days they became 3-celled (Fig. 27. G; Fig. 28. A). By repeating transverse cell-divisions, the erect uniseriate filaments became 15- to 18celled after 20 days when the longitudinal cell-divisions took place in the lower and middle parts of the filaments (Fig. 28. G). The primary attachment of the sporeling is disc-like and it later spreads radially by producing long-celled outgrowths to all directions (Fig. 28. B-F). The feature of the primary attachment resembles that of E. prolifera but differs from that of E. flexuosa, E. clathrata and E. ramulosa.

The sporelings reached to the length of $500 \mu$ after 40 days, $1 \mathrm{~mm}$ after 2 months, and $2 \mathrm{~mm}$ after 80 days (Fig. 29. C, D). With the advance of upright growth of the sporeling, the primary disc-like attachment became covered with rhizoids issued from the basal part of the erect filament (Fig. 28. H; Fig. 29. A, B). Many erect bodies were formed on the well-developed attachment and they developed into new erect filaments which became independent individuals as a result of degeneration of their basal cells (Fig. 29. $\mathbf{C}-\mathbf{H}$ ).

In 1965, a culture experiment was carried out to know the relation between sporeling development and direction of light as follows. Silde-glasses bearing attached swarmers derived from one and the same parent thallus were placed in vessels so as to be exposed to light falling either on their face or on their side. The sporelings grown in light falling on the face of a slide formed disc-like attachments which later became covered by rhizoids, whereas those grown in light falling on the side of a slide formed rhizoids from the beginning of their growth (Fig. 28. I-M). So the disclike attachment of this species is considered as a modification of rhizoids and as differing fundamentally from the basal disc of germlings in Blidingia.

[To be continued] 